\title{
The rank of climatic oscillations during MIS 11c (OHO and YHO) and post-interglacial cooling during MIS 11b and MIS 11a in eastern Poland
}

\author{
Anna HRYNOWIECKA ${ }^{1}$, Marcin ŻARSKI ${ }^{2}$, Wojciech DRZEWICKI ${ }^{3}$ \\ 1 Polish Geological Institute - National Research Institute, Marine Geology Branch, Kościerska 5, 80-328 Gdańsk, Poland \\ 2 Polish Geological Institute - National Research Institute, Rakowiecka 4, 00-975 Warszawa, Poland \\ 3 University of Wrocław, Institute of Geological Sciences, Cybulskiego 30, 50-205 Wrocław, Poland
}

Hrynowiecka, A., Żarski, M., Drzewicki, W., 2019. The rank of climatic oscillations during MIS 11c (OHO and YHO) and post-interglacial cooling during MIS $11 \mathrm{~b}$ and MIS 11a in eastern Poland. Geological Quarterly, 63 (2): 375-394, doi: 10.7306/gq. 1470

Associate Editor - Wojciech Granoszewski

Lacustrine sediments representing Marine Isotope Stage 11 (MIS 11) were found in Hermanów (SE Poland) in a present-day closed depression under a thin cover of Weichselian and Holocene deposits $(1.4 \mathrm{~m})$. These sediments filled a palaeolake created as a result of melting of a dead-ice block at the end of MIS 12. Geological research has excluded the presence of an ice sheet during MIS 12 in this area. The lobe of the ice sheet of this glaciation was located several kilometres to the west of Hermanów. The palaeolake was part of a larger palaeolakeland in southeastern Poland, formed during MIS 11. The palaeomorphology of this interglacial is evident in the contemporary relief of the area and the outline of the lakes corresponds to the pattern of the closed palaeodepressions. Based on the record of sediments from Hermanów, a new perspective regarding the sub-division of MIS 11 is presented. Two regressive phases are observed in the Holsteinian Interglacial (MIS 11c) - OHO and YHO. The subsequent substages with five cold fluctuations according to the newest stratigraphic standards should be assigned to MIS $11 \mathrm{~b}$ with a very clear cooling and a slightly warmer MIS $11 \mathrm{a}$. Carbon isotopic composition of organic matter corroborates geological and environmental analysis. The isotopic composition suggests two cooling periods: $\mathrm{OHO}$ and MIS 11b. Stable climatic conditions with little temperature fluctuations persisted between the cooling periods.

Key words: substages of MIS 11, Mazovian/Holsteinian Interglacial, MIS 12 and MIS 10 glaciation range, palaeoclimate changes, E Poland palaeolakeland, Carbon isotope.

\section{INTRODUCTION}

MIS 11c (Marine Isotope Stage 11c) is considered one of the longest (Howard, 1997; Lisiecki and Raymo, 2005; Tzedakis et al., 2012) and warmest (Howard, 1997; Coletti et al., 2015) Middle Pleistocene interglacials. Based on simulations of climate models, it is assumed that Greenland and western Antarctica were free of ice at that time (Coletti et al., 2015) or at least the ice sheet collapsed there during this unusually long warm interval (Raymo and Mitrovica, 2012; Reyes et al., 2014). MIS 11c has many terrestrial equivalents in Europe. In Poland, it is correlated with the Mazovian Interglacial (Nitychoruk et al., 2005, 2006; Marks et al., 2018), in Germany with the Holsteinian Interglacial (Koutsodendris et al., 2010), in France with the Praclaux Interglacial (de Beaulieu et al., 2001), and in

\footnotetext{
* Corresponding author, e-mail: ahry@pgi.gov.pl

Received: December 12, 2018; accepted: April 28, 2019; first published online: June 4, 2019
}

Britain with the Hoxnian Interglacial (Ashton et al., 2008; Tye et al., 2016). In eastern Europe, MIS 11c is correlated with the Alexandrian Interglacial in Belarus and with the Likhvinian Interglacial in Ukraine (Lindner et al., 2006).

Discrepancies in the correlation of the Holsteinian are evident. Most authors place it in MIS 11 (Nitychoruk et al., 2006; Rohling et al., 2010; Cohen and Gibbard, 2011), whereas others in MIS 9 (Geyh and Müller, 2005). Moncel et al. (2016) underline that the distinction between these two interglacials is not always possible due to their similar climatic characteristics and relatively short duration. This is why Moncel et al. (2016) identify the Holsteinian period with MIS 11 and MIS 9.

MIS 11 climatic records are based primarily on palynology. In the lowlands of eastern Poland, pollen analysis of MIS 11c sediments was performed on a wide scale. About 40 sites were analysed, among others the Hermanów site (Figs. 1 and 2). This enabled a detailed reconstruction of the palaeoclimate and palaeoenvironmental changes in this period. In the majority of the palynologically examined successions, an older intra-interglacial oscillation in MIS 11c was recorded, i.e. the $\mathrm{OHO}$ (Koutsodendris et al., 2010; e.g., Bińka and Nitychoruk, 1995; Krupiński, 1995; Hrynowiecka et al., 2014; Hrynowiecka and Winter, 2016; Hrynowiecka and Pidek, 2017). The younger os- 


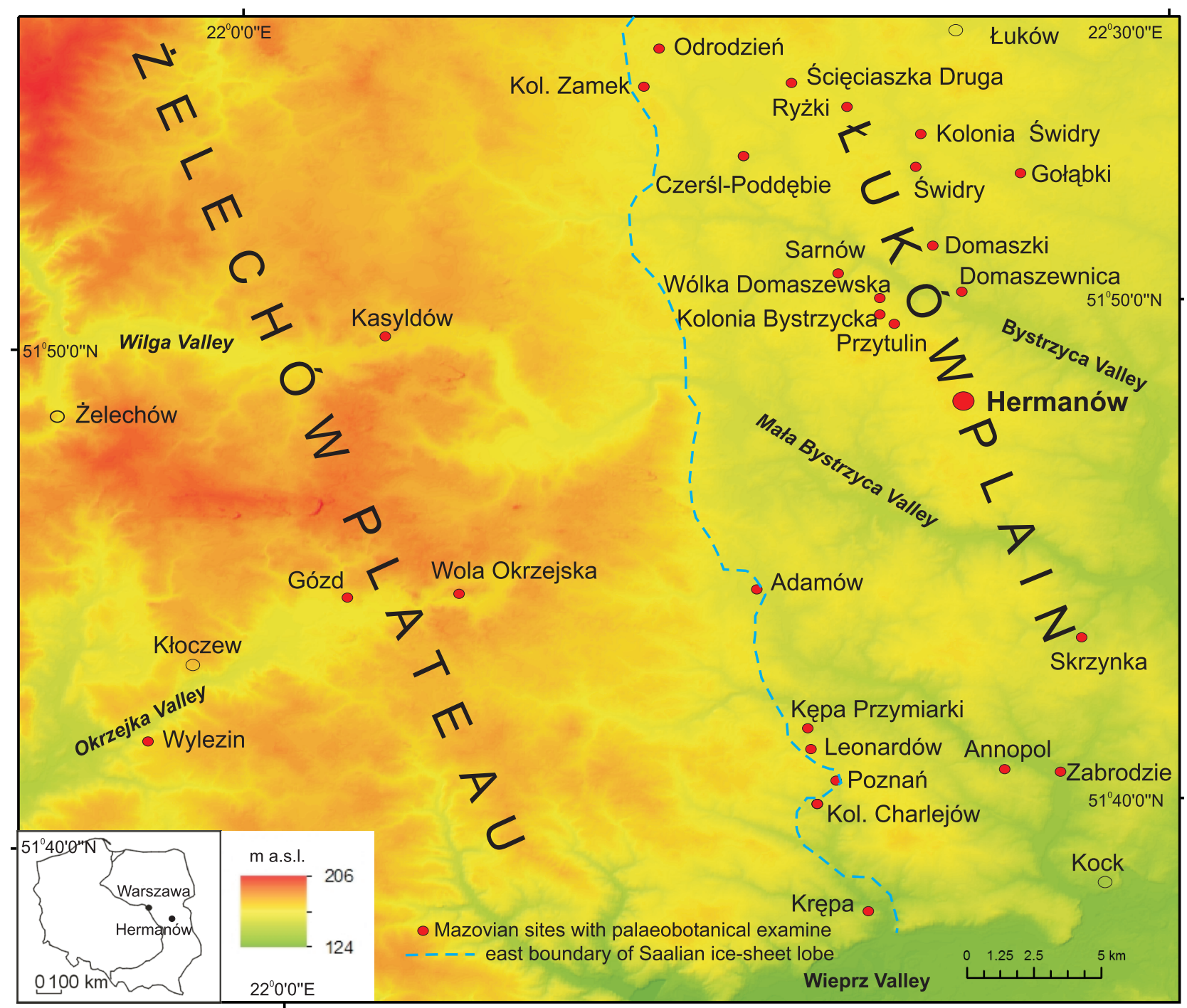

Fig. 1. The sites of palaeobotanical study of Mazovian/Holsteinian Interglacial profiles in eastern Poland, considering the range of the east boundary of the Saalian ice sheet lobe

cillation, YHO (Koutsodendris et al., 2010), is less clearly expressed in this area and therefore rarely distinguished in the analysed successions (e.g., Hrynowiecka and Winter, 2016; Hrynowiecka and Pidek, 2017).

It is not clear whether the Holsteinian/Mazovian Interglacial encompasses the entire MIS 11 (de Beaulieu et al., 2001; de Abreu, 2005) or only the MIS 11c substage (e.g., Ashton et al., 2008; Koutsodendris et al., 2010). Traditionally, MIS 11 is subdivided into three substages: $a, b$ and $c$, where MIS $11 \mathrm{c}$ is the earliest, longest and warmest substage (e.g., Tzedakis et al., 2001, 2012; Kleinen et al., 2014). However, many researchers recognize later/younger substages in various zones of the Northern Hemisphere and the subdivision of MIS 11 into 5 phases (e, d, c, b, a) is commonly accepted (e.g., Prokopenko et al., 2001; Ashton, 2010; Fawcett et al., 2011; Railsback et al., 2015). After applying molecular palaeotemperature proxies to reconstruct the mean annual temperature (MAT), Fawcett et al. (2011) stated that the temperature during MIS 11d and 11b was lower by $\sim 2^{\circ} \mathrm{C}$ in New Mexico. Ashton (2010) attributed to MIS $11 \mathrm{~d}$ and $11 \mathrm{~b}$ the phases with a sufficiently cool climate, during which parkland conditions with Salix herbacea and Betula nana prevailed in Britain. He argued that substages 11e, c and a were warmer and substages $11 \mathrm{~d}$ and $\mathrm{b}$ were colder. Two warmth maxima in MIS 11c and 11a have been confirmed by research in Arctic Russia (at 409 and 423 ka; Melles et al., 2012; Vogel et al., 2013; Coletti et al., 2015). They are evidenced by the Sea Surface Temperature (SST) reconstructions in the mid-latitude North Atlantic, which show also two temperature peaks ( 405 and $\sim 20 \mathrm{ka}$; Voelker et al., 2010), where the younger peak encompassed the interglacial thermal maximum (Rodrigues et al., 2011), separated by a short and minor cooling (MIS 11b?). The third relatively warm substage was the youngest MIS 11a (Fawcett et al., 2011). In addition, the MIS 11e substage (Railsback et al., 2015) represents a very short period closely after the MIS 12/11 transition, which has not yet been documented in palynological records from Europe. It should be emphasized that the division of MIS 11 into five substages has a local character and is not related to the global stratigraphic scheme for MIS 11 (Cohen and Gibbard, 2011).

However, direct correlation of terrestrial deposits with marine/ice cores (e.g., Lisiecki and Raymo, 2005; Voelker et al., 2010 ) is not possible, because records of marine isotopes are 


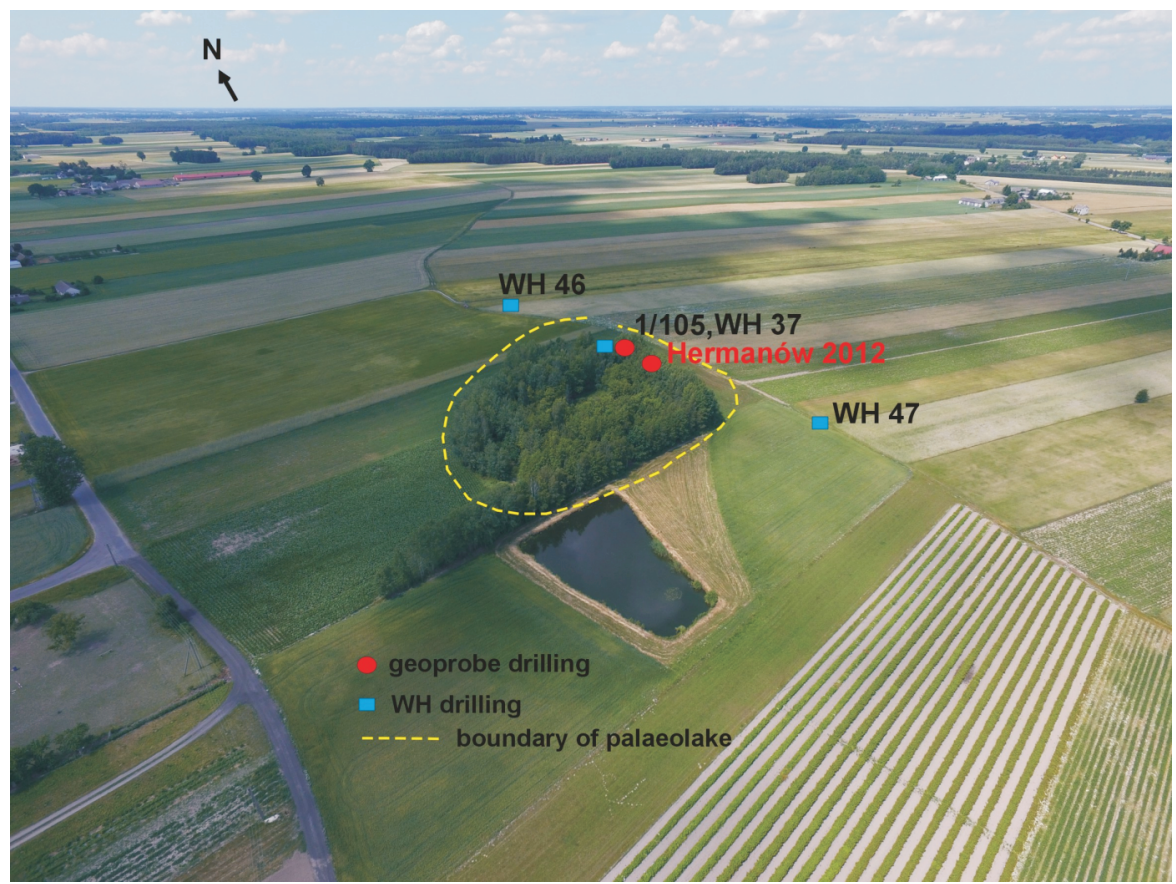

Fig. 2. The distribution of hand probe (WH drilling) and geoprobe profiles included in the paper and a potential outline of the Hermanów Lake shoreline (phot. W. Żarski)

similar to terrestrial records only in general outline (Tzedakis et al., 1997; Bińka and Marks, 2018). Already Tzedakis et al. (1997) stated asynchronicity between the beginning of terrestrial and marine records, because the pollen sequences are more sensitive to climatic changes than oxygen isotopes in marine cores. Similar uncertainties with the correlation of Tenaghi Philippon data to the North Atlantic marine record from ODP Site 983 are in Vakhrameeva et al. (2018). It was also suggested that neither oxygen isotopes nor the model of Milankovitch cycles are good patterns for the correlation of terrestrial pollen records, mainly due to the difficulty in estimating the sedimentation rate in individual deposits (Tzedakis et al., 1997). Comparison of marine and terrestrial records requires a careful consideration of age model uncertainties (Koutsodendris et al., 2014). Even clear isotopic events can be difficult to locate in terrestrial sediments. Therefore, it is best to use terrestrial records for the correlation of other terrestrial records based on pollen chronology. The correlation, or rather non-correlation, of a high-percentage curve of arboreal pollen from the Tenaghi Phillipon profile (Tzedakis et al., 2004, 2006) with the LR04 marine stack (Lisiecki and Raymo, 2005) well-illustrates this principle (Fig. 3). Bińka and Marks (2018) emphasize that the asynchronicity of marine/ice and terrestrial records is mainly due to the shorter course of the marine/ice intervals and the lack of detailed location of the beginning and end of warmer periods within them. Therefore, the beginning of the Holsteinian/Mazovian Interglacial in Central Europe may not coincide with the beginning of MIS 11c in the sea zone. This is caused by the retreat of the ice sheet and consequently by a delay in tree migration (Koutsodendris et al., 2012).

Based on varve counting in the Dethlingen Lake deposits (northern Germany), it was stated that the Holsteinian/Mazovian Interglacial lasted $15 \pm 1.5 \mathrm{ka}$ and must be younger than the beginning of MIS 11c (Koutsodendris et al., 2010). It is difficult to estimate the duration of the Holsteinian/Mazovian Interglacial based on LR04 core studies (Lisiecki and Raymo, 2005) and EDC3 chronology for the EPICA Dome C ice core (Jouzel et al., 2007; Parrenin et al., 2007; Fig. 3) resulting in the duration of substage MIS $11 \mathrm{c}$ at $27-28 \mathrm{ka}$ and $27 \pm 8 \mathrm{ka}$ estimated by analysis of deposits from Arctic Lake El'gygytgyn (Vogel et al., 2013). Perhaps, the answer of this incompatibility was re-drilling a new core and re-counting the varves in the Bispingen profile (Eemian Interglacial in northern Germany; Lauterbach et al., 2012). Sediments from this profile were originally estimated at 11 ka (Müller, 1974) and correlated with MIS 5e. After recounting the varves in the new profile, the duration of the Eemian Interglacial was estimated at $\sim 17$ ka (Lauterbach et al., 2012), indicating that in northern Germany it should be correlated with MIS $5 e$ and partly with MIS $5 \mathrm{~d}$. The study determined also that there were gaps in the previously drilled Bispingen profile that caused incorrect estimation of the Eemian Interglacial duration. It should be noted that a similar situation probably applies to the chronology of the Holsteinian/Mazovian Interglacial and that all estimates of the duration of this interglacial and its individual phases that based on lake deposits should be treated very carefully.

Earlier isotopic analysis from the Mazovian Interglacial (MIS 11c) focused on $\delta^{13} \mathrm{C}_{(\mathrm{CaCO} 3)}$ and $\delta^{18} \mathrm{O}_{(\mathrm{CaCO})}$ of malacofauna shells (e.g., Nitychoruk, 2000; Szymanek et al., 2016; Szymanek, 2017). Addition of $\delta^{13} \mathrm{C}_{(\mathrm{org})}$ allows for extra insight into palaeoenvironmental conditions recorded by isotopic composition of organic matter. Temperature plays a fundamental role in $\delta^{13} \mathrm{C}$ characteristics of organic matter, so that small differences in temperature will affect $\delta^{13} \mathrm{C}$ values. Data from several sources (Smith et al., 1973; Whelan et al., 1973; Lipp et al., 1991; Skrzypek et al., 2007a, b) suggest that the change in $\delta^{13} \mathrm{C}$ of various $\mathrm{C} 3$ plants per degree change in temperature varies from -1.5 to $+0.33 \%{ }^{\circ} \mathrm{C}$.

The sediments overlying MIS 11c (strictly above the interglacial part) are called in all studies the Early Liwiecian Glaciation (Marine Isotope Stage 10, corresponding to the Odranian Glaciation s.l. (Marks et al., 2018), Fuhne Glaciation in Ger- 


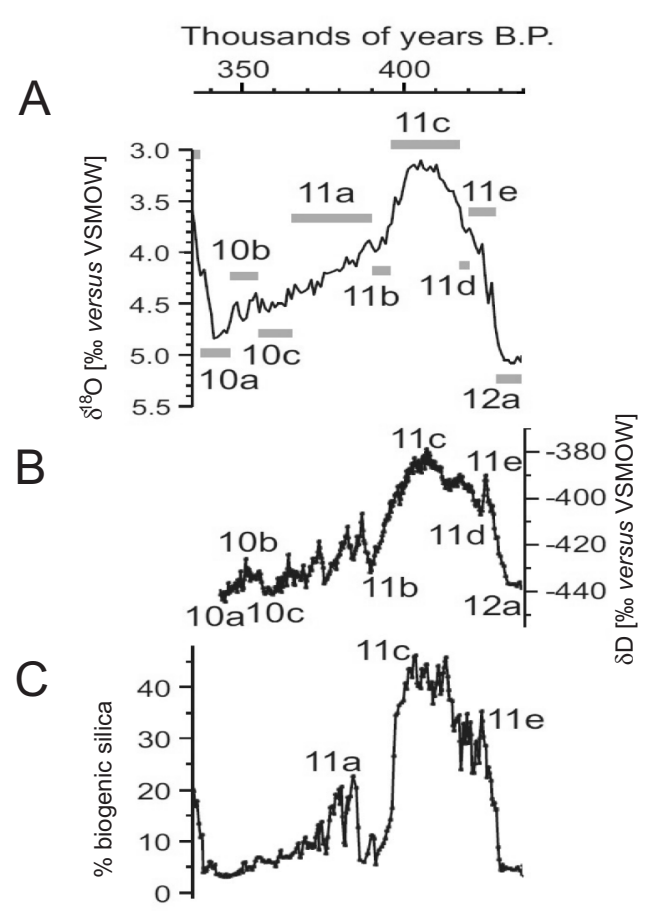

D

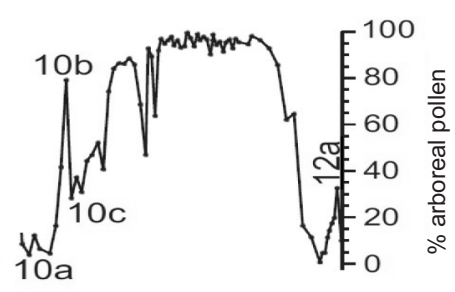

E

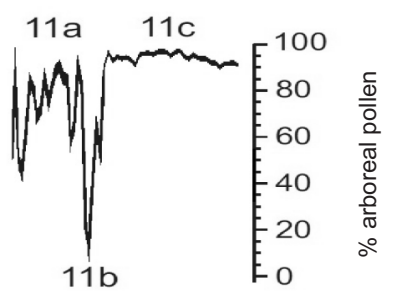

Fig. 3. Comparison of research results of MIS 11 deposits

A - LR04 marine stack (Lisiecki and Raymo, 2005); B - EPICA DOME C ice record (Jouzel et al., 2007) using chronology of Veres et al. (2013) and Bazin et al. (2013); C - Lake Baikal Record (Prokopenko et al., 2001); D - Tenaghi Phillipon (Greece) pollen record (Tzedakis et al., 2006); E Hermanów profile (this paper)

many (s.I. Saalian Glaciation; Börner, 2007), and Bargette Glaciation in France (Reille et al., 2000). They were rarely investigated in Poland due to the poorly preserved records.

Following MIS 11c in eastern Poland, the first cold substage is clearly marked in the successions (e.g., Pidek, 2003; Hrynowiecka-Czmielewska, 2010). However, profiles with a record of changes in further substages are not numerous. In Poland, the largest number of 4 cold phases ("stadials") was recognized in the Ossówka profile as the Liwiecian Glaciation (E Poland; Krupiński, 1995; Nitychoruk et al., 2005).

The Hermanów site (Fig. 1) on the Łuków Plain in SE Poland (Żarski, 2007; Żarski and Morawski, 2013) displays the full record of the Holsteinian/Mazovian Interglacial (MIS 11c) with both climatic fluctuations (OHO and $\mathrm{YHO}$ ) and further MIS 11, with a record of 5 cold substages, the first of which should be considered as MIS $11 \mathrm{~b}$ and the next substages as MIS 11a.

\section{MATERIAL AND METHODS}

\section{GEOLOGICAL SETTING}

The Hermanów site $\left(22^{\circ} 22^{\prime} \mathrm{E}, 51^{\circ} 48^{\prime} \mathrm{N}\right)$ is located in southeastern Poland on the Łuków Plain (Kondracki, 2002), about $105 \mathrm{~km}$ to the east of Warsaw (Fig. 1). The study area was covered by ice sheets of several glaciations in the Early and Middle Pleistocene (Marks, 2004) and is located in the western part of a palaeolakeland from the Mazovian Interglacial, which is visible in the contemporary morphology of the area. Numerous sites with lake sediments of the Mazovian/Holsteinian Interglacial occur in the study area and further to the east (e.g., Nitychoruk, 1994, 2000; Albrycht et al., 1997; Lindner and Marks, 1999; Krupiński, 2000; Żarski et al., 2005; Lindner et al., 2007; Małek and Pidek, 2007; Małek, 2008; Żarski, 2008, 2009; Pidek et al., 2011; Terpiłowski et al., 2014; Hrynowiecka et al., 2014).

Like the neighbouring sites (Przytulin, Kolonia Bystrzycka, Wólka Domaszewska, Domaszewnica; Żarski 2008, 2009; Fig. 1), the Hermanów site is located on a denuded post-glacial plateau, composed mainly of glacial tills from the Sanian 2 Glaciation (Elsterian, MIS 12; Żarski, 2008, 2009; Żarski et al., 2009; Terpiłowski et al., 2014). To the west of Hermanów (Fig. 1), the plateau surface is built of post-glacial deposits of the Odra Glaciation (Saalian). This is the zone of the maximum range of the Odra Glaciation (Saalian) ice sheet. The Hermanów site is located within a very well-preserved closed basin on the plateau (Fig. 2), characterized by a sub-circular shape with the diameter of about $300 \mathrm{~m}$. The outline of the contemporary small peatbog basin strictly corresponds to the shape of the reservoir from the Mazovian Interglacial (Fig. 2). This case is typical for the area, where the palaeolakeland from the Mazovian Interglacial is visible on the surface of the present-day post-glacial plateau. The terrain surface lies at 164-165 m a.s.l., like in Przytulin, Kolonia Bystrzycka and Wólka Domaszewska (Fig. 1).

Lacustrine sediments in Hermanów were drilled with a hand probe to a depth of $4.3 \mathrm{~m}$ during a geological mapping survey in 2004 . In the same year, a mechanical probe drilled 14 m of sediment, and in 2005 a geoprobe pierced the deposits to a depth of $8.4 \mathrm{~m}$ (Fig. 4). The thickness of the lacustrine organic sediments was $6.48 \mathrm{~m}$ in the mechanical probe and $6.06 \mathrm{~m}$ in the geoprobe. Based on pollen analysis, the age of the sediments was determined by Krupiński $(2004,2009)$ as the Mazovian Interglacial. In 2012, another geoprobe drilling reached a depth of $7.75 \mathrm{~m}$. In addition, mechanical probes were made to the north and south of the palaeolake (Fig. 4).

\section{DESCRIPTION OF THE SEDIMENTS}

The palaeolake basin in Hermanów formed as a result of melting of a dead-ice block at the end of the Sanian 2 Glaciation (Elsterian, MIS 12). The Mazovian Interglacial sediments are underlain by fine-grained sands and silty sands (Table 1 and Fig. 4), accumulated in a water reservoir immediately after the melting of the dead-ice block. The lacustrine succession of the Mazovian Interglacial (MIS 11c) begins with fine-grained and silty sands $(7.30-6.98 \mathrm{~m})$, overlain by laminated dark grey silts 


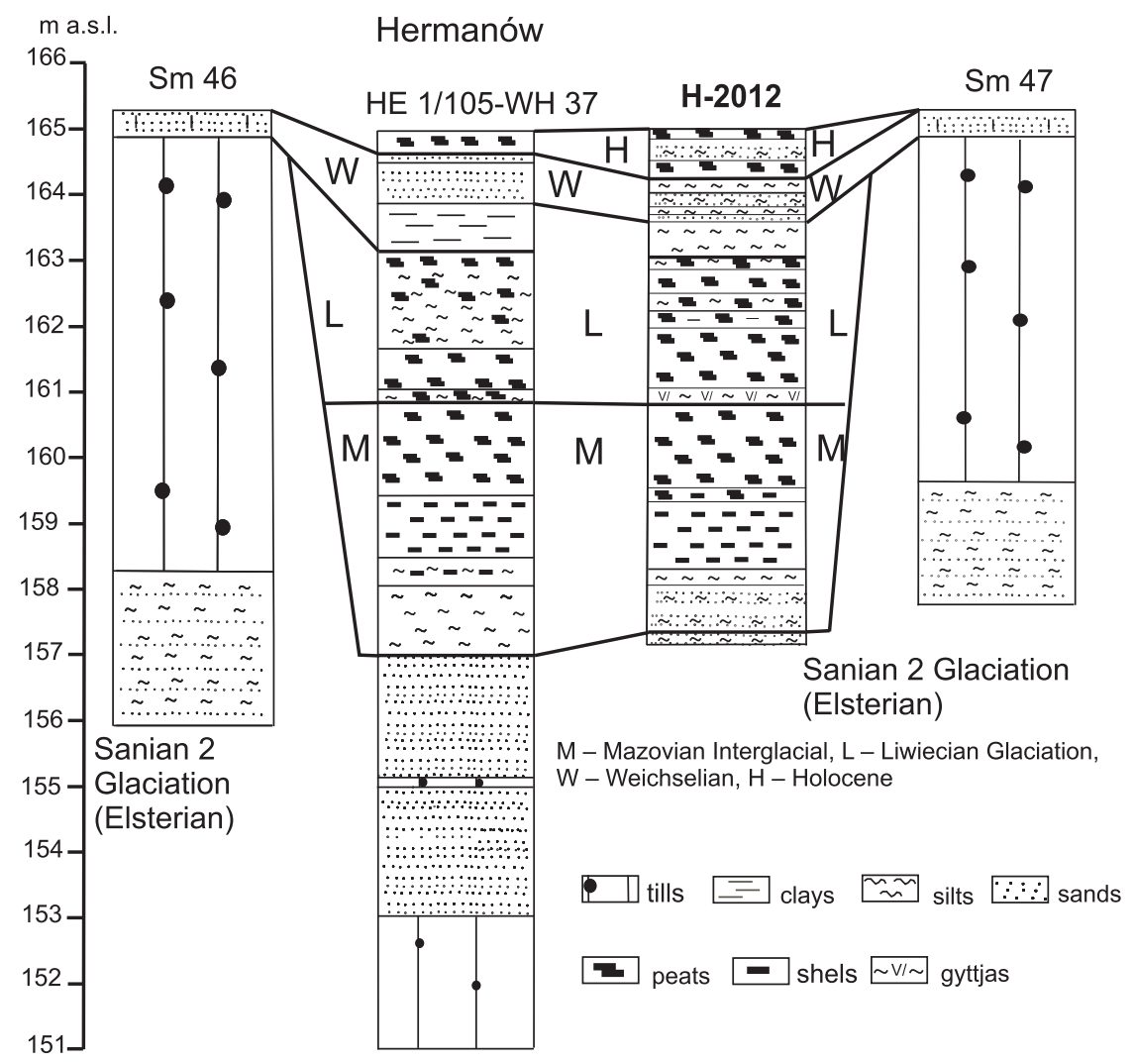

Fig. 4. Comparison of sediments from hand probes (WH drilling) and geoprobe profiles from the Hermanów site

$(6.98-6.70 \mathrm{~m})$, peaty shales $(6.70-5.72 \mathrm{~m})$, and shaly peats (5.72-5.51 m). The Mazovian Interglacial lake series ends with brown-black, poorly decomposed peats with numerous plant macroremains $(5.72-4.25 \mathrm{~m})$. The thickness of the Mazovian Interglacial lacustrine sediments is $3.05 \mathrm{~m}$ (Table 1 and Fig. 4).

The interglacial sediments are covered with lake deposits of cold climatic conditions, which should be correlated with MIS $11 \mathrm{~b}$, followed by slightly improving conditions, which should be correlated with MIS 11a. They begin with grey-olive gyttja (4.25-3.98 m), overlain by poorly decomposed peats with numerous macroremains $(3.98-2.80 \mathrm{~m})$, strongly decomposed clayey peats (2.80-2.56 m), brown-black strongly decomposed peats $(2.56-2.15 \mathrm{~m})$, poorly laminated brown-grey silts (2.15-2.03 m), and a layer of fine-grained sands (2.01-2.03 m). The sedimentation of the lake reservoir terminates with greybrown, weakly laminated silts (2.03-1.42 m). Above occur finegrained silty sands and silts $(1.42-0.73 \mathrm{~m})$ correlated with the Weichselian Glaciation (Late Glacial, MIS 2), overlain by Holocene peats with an interbedding of silty sands $(0.73-0.00 \mathrm{~m}$; Table 1 and Fig. 4).

\section{POLLEN ANALYSIS}

All 56 pollen samples were taken from a core from the depth interval of $180-730 \mathrm{~cm}$. The organogenic sediments were sampled every $10 \mathrm{~cm}$ at a volume of $1 \mathrm{~cm}^{3}$. All samples for pollen analysis were acetolized according to Erdtman's method (1960), modified using HF (Berglund and Ralska-Jasiewiczowa, 1986). Before acetolysis, one tablet of the Lycopodium indicator was added per $1 \mathrm{~cm}^{3}$ of each sample to determine the absolute con- centration of sporomorphs (Stockmar, 1971). Pollen spectra for each sample were counted on two slides with a surface area of $20 \times 20 \mathrm{~mm}$. Counting was carried out up to $\sim 500$ grains of pollen. Only in cases of extremely low frequency, about 300 pollen grains were counted.

The percentage calculations are based on the basic sum, which includes pollen grains of trees and shrubs (AP), and herbaceous plants and dwarf shrubs (NAP). The percentage proportions of other plants were calculated in relation to the basic sum.

The palynological results are presented as percentage pollen diagrams (Figs. 5-8, and significantly simplified in Fig. 3E) prepared using POLPAL software (Nalepka and Walanus, 2003). The pollen succession from Hermanów was subdivided into 21 local pollen assemblage zones (L PAZs) numbered from the bottom to the top of the succession.

All samples are stored at the Polish Geological Institute National Research Institute.

\section{GEOLOGICAL ANALYSIS}

\section{ANALYSIS OF PETROGRAPHIC COMPOSITION}

Petrographic analysis of gravels washed out of the glacial till was performed for samples taken from the WH46 borehole (Figs. 2 and 4 ) in the following depth intervals: $2.0-4.0 \mathrm{~m}$; 4.0-6.0 $\mathrm{m}$ and $8.0-10.0 \mathrm{~m}$. The simplified petrographic analysis included macroscopic determination of the petrographic group of the analysed gravel grains (fraction 5-10 mm; Krygowski, 1956, 1967; Kenig, 1998; Lisicki, 2003). 
Table 1

Detailed description of sediments from the Hermanów site, including layer thickness

\begin{tabular}{|c|c|c|c|}
\hline Depth [m] & Colour & Deposits & Stratigraphy \\
\hline $0.0-0.17$ & brown-reddish & non-decomposed peats & \multirow{5}{*}{ Holocene } \\
\hline $0.17-0.37$ & brown & silty sands with humus & \\
\hline $0.37-0.44$ & brown & peats & \\
\hline $0.44-0.73$ & brown-black & clayey peats & \\
\hline $0.73-0.75$ & brown-black & clayey silts & \\
\hline $0.75-0.96$ & light brown & sits & \multirow{4}{*}{ Weichselian } \\
\hline $0.96-1.10$ & brown-reddish & fine grain sands & \\
\hline $1.10-1.33$ & ligh brown & silty sands & \\
\hline $1.33-1.42$ & light grey & fine grain sands & \\
\hline $1.42-1.52$ & grey-brown & laminated silts & \multirow{13}{*}{ Liwiecian Glaciation } \\
\hline $1.52-1.53$ & light grey & fine grain sands & \\
\hline $1.53-2.01$ & grey-brown & laminated silts & \\
\hline $2.02-2.03$ & brown & fine grain sands & \\
\hline $2.03-2.15$ & grey-brown & laminated silts & \\
\hline $2.15-2.17$ & brown-black & peaty silts & \\
\hline $2.17-2.56$ & brown-black & well-decomposed peats & \\
\hline $2.56-2.80$ & brown-black & well-decomposed clayley peats & \\
\hline $2.80-3.05$ & black & $\begin{array}{l}\text { poorly decomposed clayey peats } \\
\text { with macrofosills }\end{array}$ & \\
\hline $3.05-3.25$ & black & poorly decomposed peats with macrofosills & \\
\hline $3.25-3.50$ & brown-black & non-decomposed peats with macrofosills & \\
\hline $3.50-3.98$ & brown-black & poorly decomposed peats with macrofosills & \\
\hline $3.98-4.25$ & grey-olive & gyttja & \\
\hline $4.25-5.21$ & brown-black & poorly decomposed peats with macrofosills & \multirow{7}{*}{$\begin{array}{l}\text { Mazovian } \\
\text { Interglacial }\end{array}$} \\
\hline $5.21-5.51$ & brown-black & non-decomposed peats with macrofosills & \\
\hline $5.51-5.72$ & brown-black & shaly and peats with macrofosills & \\
\hline $5.72-6.70$ & dark brown & shaly peaty & \\
\hline $6.70-6.92$ & dark grey & silts with macrofosills & \\
\hline $6.92-6.98$ & dark grey & silts with fine grain sands & \\
\hline $6.98-7.32$ & grey & silty sands with fine grain sands & \\
\hline $7.32-7.75$ & grey & fine grain sands & Elsterian Glaciation \\
\hline
\end{tabular}

ANALYSIS OF GRAIN SIZE COMPOSITION

Grain size analysis was performed for samples of sand and silt deposits from the depth interval $1.42-0.17 \mathrm{~m}$. The large gravel $>5 \mathrm{~mm}$, gravel $2-5 \mathrm{~mm}$, sand $0.1-2 \mathrm{~mm}$, silt $0.01-0.1 \mathrm{~mm}$, and clay $0.001-0.01 \mathrm{~mm}$ (Gradziński et al., 1986) fractions were isolated using the sieve-areometric method (Mycielska-Dowgiałło and Rutkowski, 1995). The grain size parameters were calculated according to the Folk and Ward method (1957).
ANALYSIS OF HEAVY MINERALS COMPOSITION

Analysis of heavy minerals was performed on samples of sediments from the depth intervals $1.42-1.33 \mathrm{~m}$ and $0.96-1.10 \mathrm{~m}$. Sediments were separated by dry sieving. The studied fraction $(0.1-0.25 \mathrm{~mm})$ was treated with a heavy liquid of density above $2.9 \mathrm{~g} / \mathrm{cm}^{3}$ (sodium polytungstate $3 \mathrm{Na}_{2} \mathrm{WO}_{4}$. - $9 \mathrm{WO}_{3} \cdot \mathrm{H}_{2} \mathrm{O}$ ). After separation of heavy minerals, $\mathrm{HCl}$ was used to remove calcium carbonate. The remaining heavy min- 


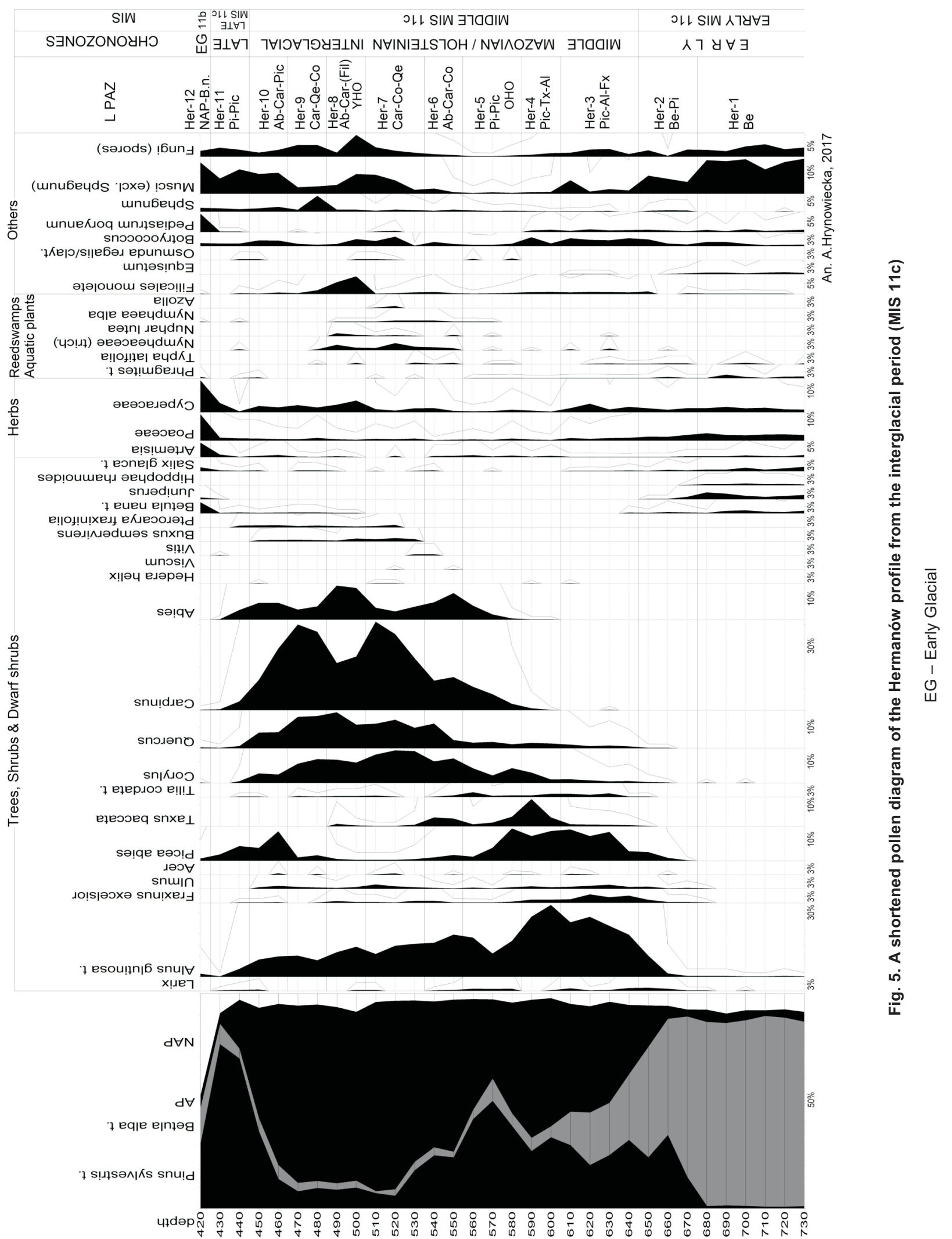




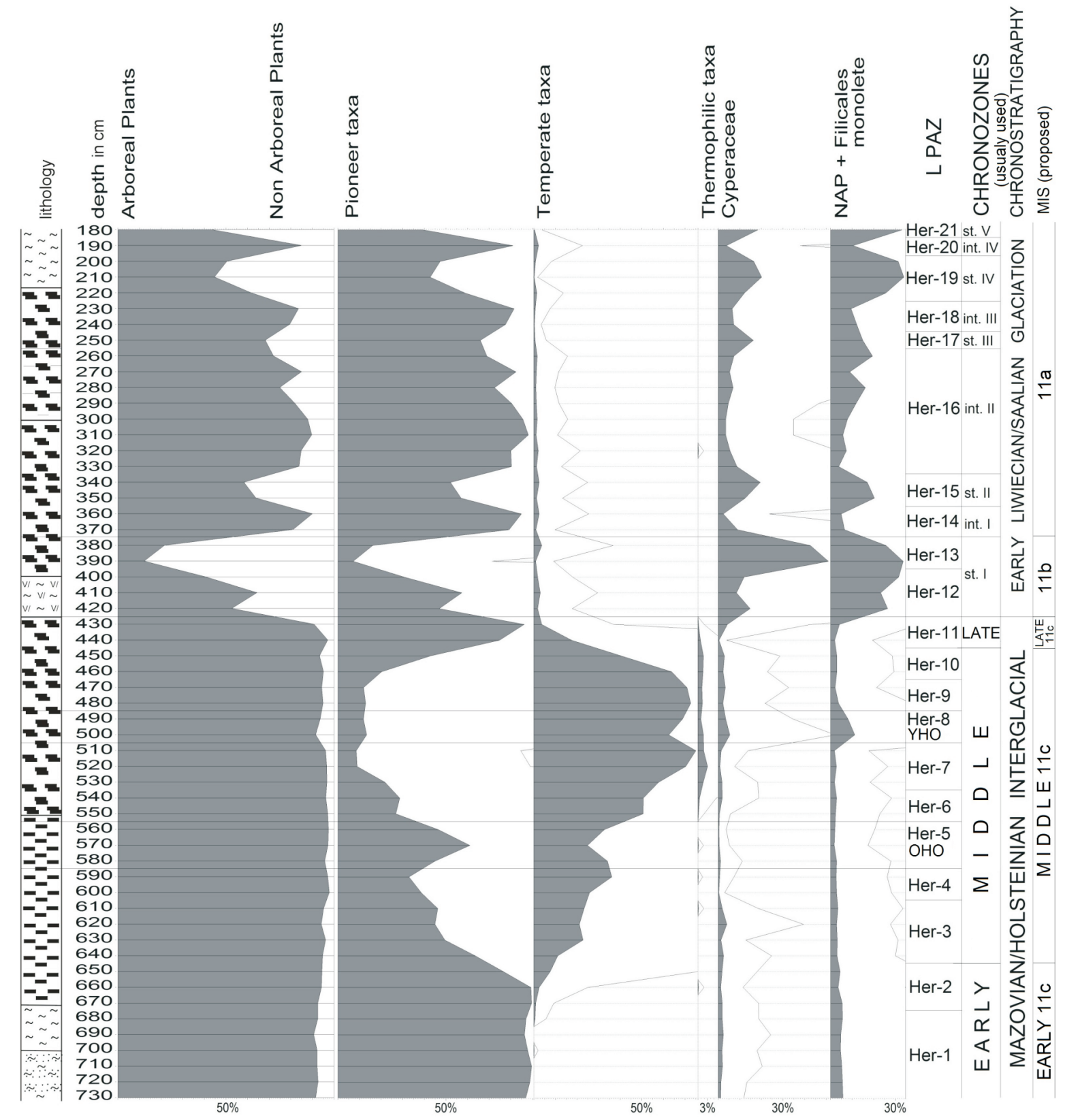

Fig. 6. Schematic presentation of pollen analysis results compared with lithology data from the Hermanów profile

Pioneer taxa includes: Pinus and Betula pollen; temperate taxa include: Alnus, Fraxinus, Ulmus, Picea, Taxus, Corylus, Quercus, Carpinus and Abies pollen; thermophilic taxa include: Hedera helix, Viscum, Vitis, Buxus and Pterocarya pollen; for explanation of lithology see Figure 4

erals were identified and counted under a petrographic microscope (Jęczmyk and Kanasiewicz, 1970; Klein and Hurlbut, 1993; Racinowski, 1995. Marcinkowski and Mycielska-Dowgiałło, 2013). The percentage of transparent and opaque minerals, which altogether represent $100 \%$, was studied.

$$
\begin{aligned}
& \text { ANALYSIS OF THE CALCIUM CARBONATE } \\
& \text { CONTENT }
\end{aligned}
$$

The analysis was performed on the fraction below $0.1 \mathrm{~mm}$ using the Scheibler apparatus (Myślińska, 2016).

\section{ANALYSIS OF FROSTING AND ROUNDNESS OF QUARTZ GRAINS}

The analysis was performed on the $0.5-1 \mathrm{~mm}$ fraction grains using the Cailleux method, modified by Goździk (1981) and Mycielska-Dowgiałło and Rutkowski (1995).

\section{${ }^{14}$ C DATING}

Radiocarbon dating of one sample taken from the base of the peat layer $(0.7 \mathrm{~m})$ was made at the Gliwice Absolute Dat- 


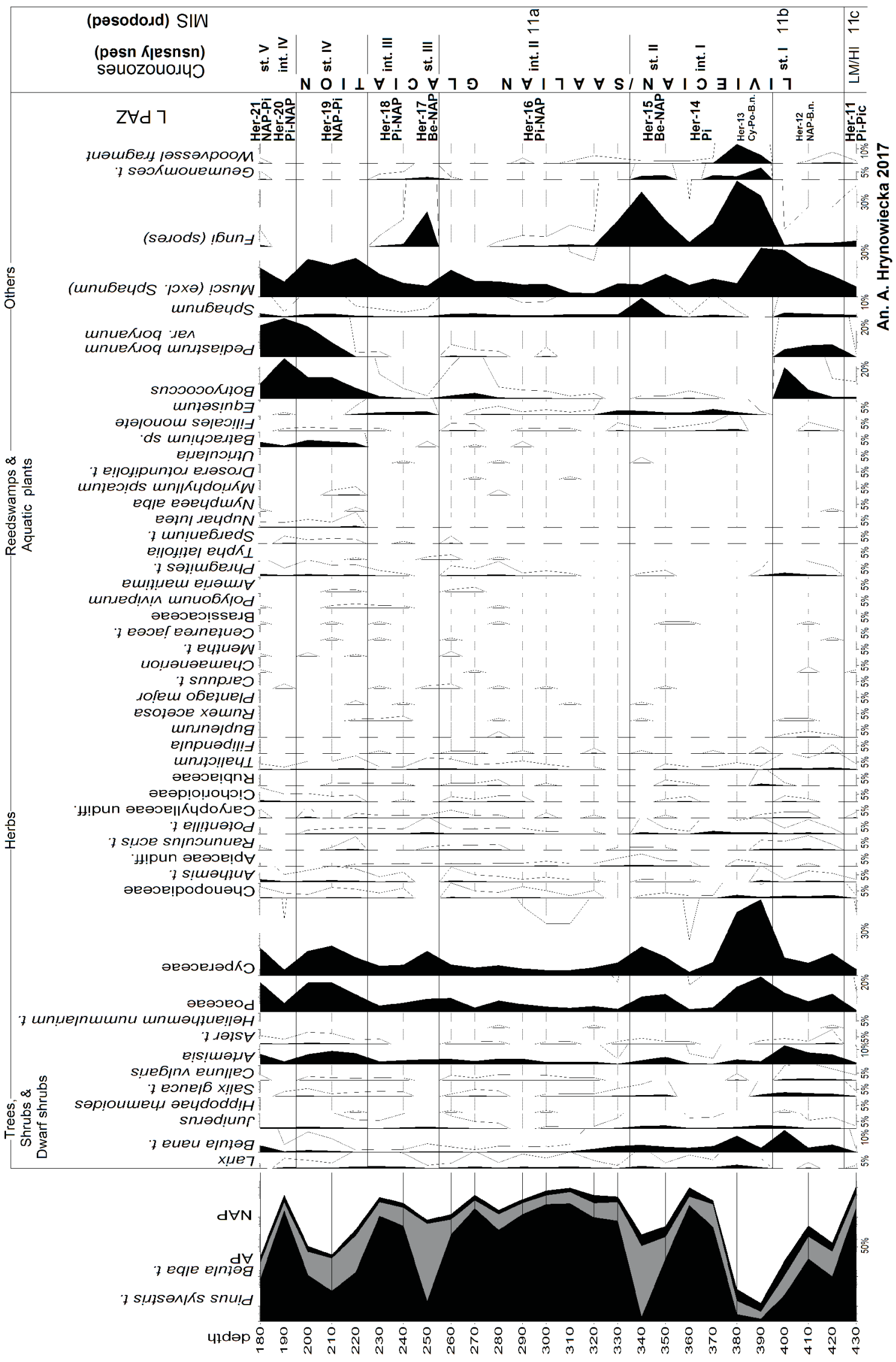




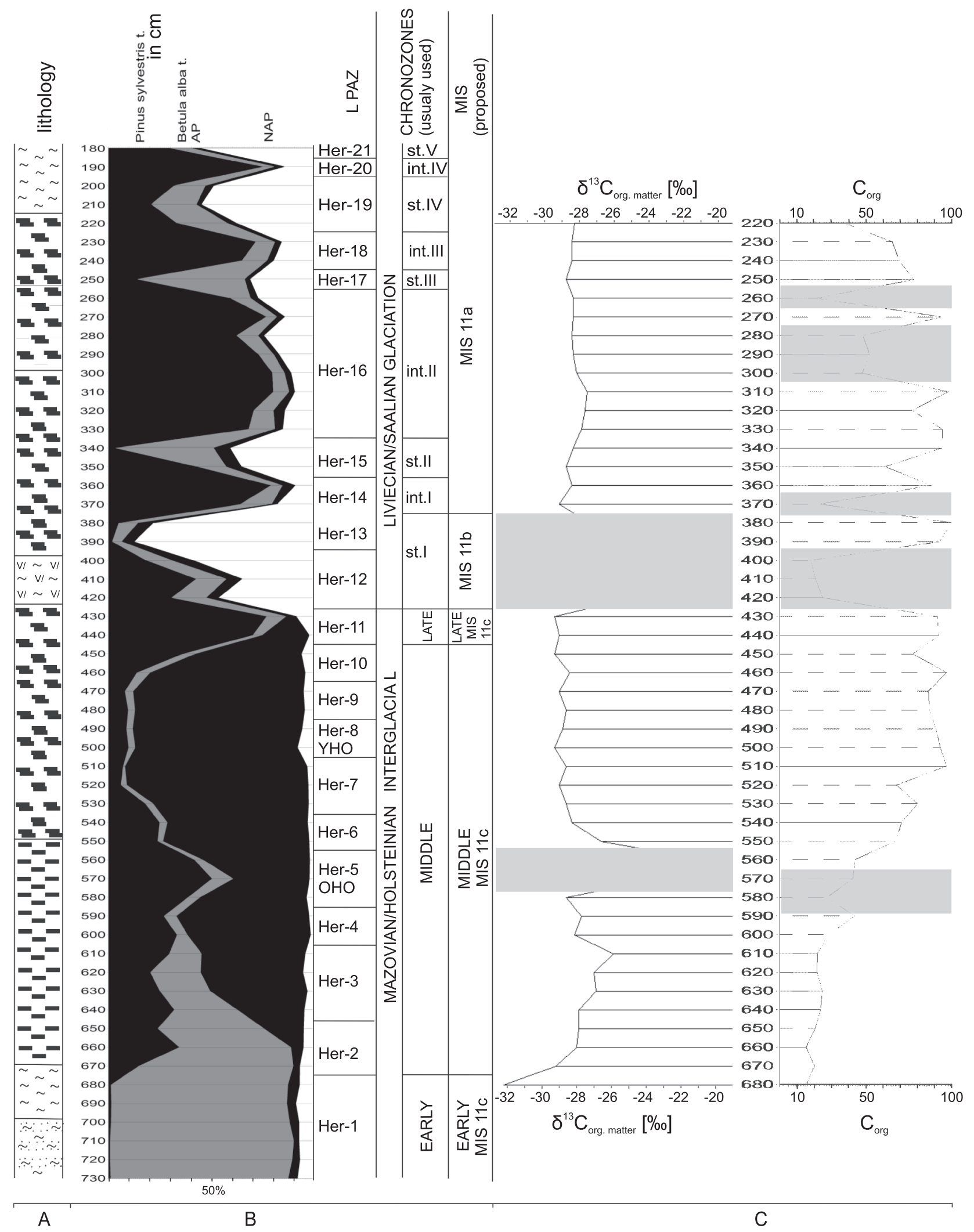

Fig. 8. Results of ${ }^{13} \mathrm{C}$ isotope analysis and organic matter analysis (C) correlated with pollen analysis results (B) and lithology (A)

For explanation of lithology see Figure 4 grey belts indicate periods of cooling 
ing Method Centre (Michczyński, 2017). The radiocarbon conventional date was calibrated using OxCal 4.2 software (Bronk Ramsey et al., 2010) and the IntCal13 calibration curve (Reimer et al., 2013). Calibrated BP years were used in these studies.

\section{ISOTOPIC ANALYSIS}

Chemical and isotopic analyses were performed at the Isotope Geology and Geoecology Laboratory of the Institute of Geological Sciences, Wrocław University. Samples were washed with $4 \% \mathrm{HCl}$ to remove inorganic carbon, freeze dried and homogenized. $5 \mathrm{mg}$ of pure organic matter were placed within quartz ampoules with $\mathrm{CuO}$, heated for 10 hours at $900^{\circ} \mathrm{C}$ and for 4 hours at $650^{\circ} \mathrm{C}$. Combustion products, $\mathrm{CO}_{2}, \mathrm{H}_{2} \mathrm{O}$ and $\mathrm{NO}_{x}$ were cryogenically separated and pure $\mathrm{CO}_{2}$ was used for isotopic analysis. All isotopic compositions in this paper are reported in the standard $\delta$-notation (the relative difference, in parts per thousand $(\%)$, between the isotope ratio of the sample and the international standard). We used the "multiple-point" normalization technique (Paul et al., 2007) to normalize all raw isotopic data to isotope reference scales; $\delta^{13} \mathrm{C}$ is reported in the VPDB scale (Vienna PeeDee Belemnite). The following International Atomic Energy Agency (IAEA) reference standards were analysed with each set of samples, specific to the isotope of interest and utilized for normalization: NBS22, NBS18 and USGS24. The uncertainties associated with stable isotope analyses are $0.2 \%$ for $\delta^{13} \mathrm{C}$.

The isotopic fractionation proceeds in two stages:

- adsorption and diffusion of $\mathrm{CO}_{2}$ into the plant tissue;

- the initial carboxylation (e.g., O'Leary, 1981).

Consequently, the cumulated of ${ }^{12} \mathrm{C}$-enrichment of the plant tissue with respect to the atmospheric carbon dioxide is about 18-27\% (C3 plants) and 4-6\% (C4 plants), (O'Leary, 1981; Lajtha and Marshal, 1994).

\section{ANALYSIS OF TOTAL ORGANIC CONTENT (TOC)}

Organic matter content was measured following the procedure of Gale and Hoare (1991). Samples were dried at $105^{\circ} \mathrm{C}$ and combusted in an oven at $550^{\circ} \mathrm{C}$ for $8 \mathrm{~h}$. Results are expressed as percent of dry weight.

\section{RESULTS}

\section{RESULTS OF POLLEN ANALYSIS}

Analysis of 56 samples from the Hermanów profile enabled the identification of 112 taxa, represented by 28 trees and shrubs (Arboreal Plants), 5 dwarf shrubs, 48 terrestrial herbs (Non-Arboreal Plants), 17 aquatic and reed swamp plants, 7 Pteridophyta, 2 Bryophyta, 2 Algae and spores of Fungi, Gaeumannomyces t., and Woodvessel fragments. The diagrams include only selected taxa. All marked taxa are listed as occurring in the detailed description of Local Pollen Assemblage Zones (L PAZs; Table 2).

\section{RESULTS OF GEOLOGICAL ANALYSIS}

PETROGRAPHIC COMPOSITION

The interval to a depth of $8 \mathrm{~m}$ (Table 3 ) contains mainly flints (local rocks), crystalline rocks, and very compact, highly diagenized sandstones of Scandinavian origin with a silica matrix, passing into quartzites. Petrographic composition indicates intensive weathering processes of the upper parts of the glacial till. Carbonate rocks have been destroyed probably by weathering processes. From a depth of $8.0 \mathrm{~m}$ downwards, there are mainly Scandinavian limestones and minor amounts of Scandinavian dolomites. Due to the poor petrographic composition of gravels found in the glacial tills in the WH46 Hermanów profile, comparison with other profiles, in which glacial tills of the Elsterian Glaciation were analysed, was not possible.

GRAIN SIZE

The sand fraction of the Hermanów profile is dominated by fine-grained sands with an admixture of well-sorted mediumgrained sands. Quartz grains are well-rounded and their surface is matted due to aeolian processes.

\section{HEAVY MINERALS}

Minerals resistant and very resistant to mechanical destruction, with a specific weight between $3 \mathrm{~g} / \mathrm{cm}^{3}$ to slightly over $4 \mathrm{~g} / \mathrm{cm}^{3}$, predominate in the analysed samples. Garnet, tourmaline, zircon, staurolite, topaz, ilmenite and disthene are determined through to their specific and characteristic appearance using a microscope. In their majority, they account for over $90 \%$ of the composition of the studied heavy fraction. The grains are moderately and well-rounded, with round, oval and ellipsoidal shapes and rounded sides. Minerals non-resistant to destruction (amphibole, pyroxene) represent less than $10 \%$ of the studied fraction. A significant predominance of minerals resistant to destruction over non-resistant minerals is also reflected in the $A / G$ index, which is the amphibole to garnet ratio. Based on the minerals studied, it can be concluded that the sediments were transported in an aquatic setting, and later they underwent strong aeolization in periglacial conditions.

\section{CALCIUM CARBONATE} CONTENT

The analysed sand and silty deposits are characterized by a constant, low content of calcium carbonate, which is from tenths to $1 \%$ in all samples.

\section{RADIOCARBON DATING}

The absolute age of the sample taken from the base of the peat from a depth of $0.7 \mathrm{~m}$ was determined at $5600-5265$ calendar age calibrated BP (88.3\%, GdS-3449; Michczyński, 2017; Table 4), which corresponds to the Subboreal Period of the Holocene (Ralska-Jasiewiczowa et al., 1998). 
Detailed description of local pollen assemblage zones in the Hermanów profile

\begin{tabular}{|c|c|c|c|}
\hline & 营氞 & 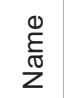 & Detailed description of local pollen assemblage zones \\
\hline$\frac{\bar{I}}{\frac{\pi}{I}}$ & $\begin{array}{l}0 \\
0 \\
0 \\
1 \\
1 \\
ల \\
1\end{array}$ & $\underset{\mathbb{D}}{\frac{\pi}{3}}$ & 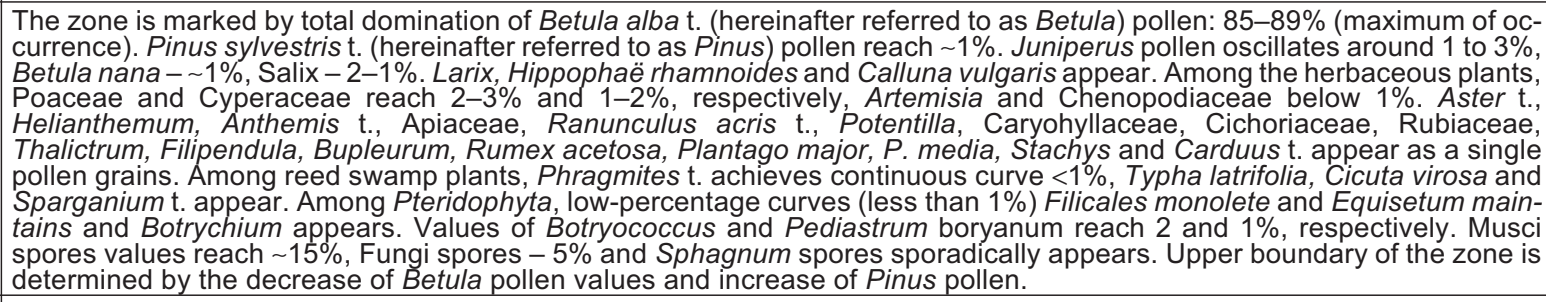 \\
\hline $\begin{array}{l}\frac{N}{\pi} \\
\frac{1}{I}\end{array}$ & $\begin{array}{l}0 \\
0 \\
0 \\
1 \\
0 \\
0 \\
0\end{array}$ & & 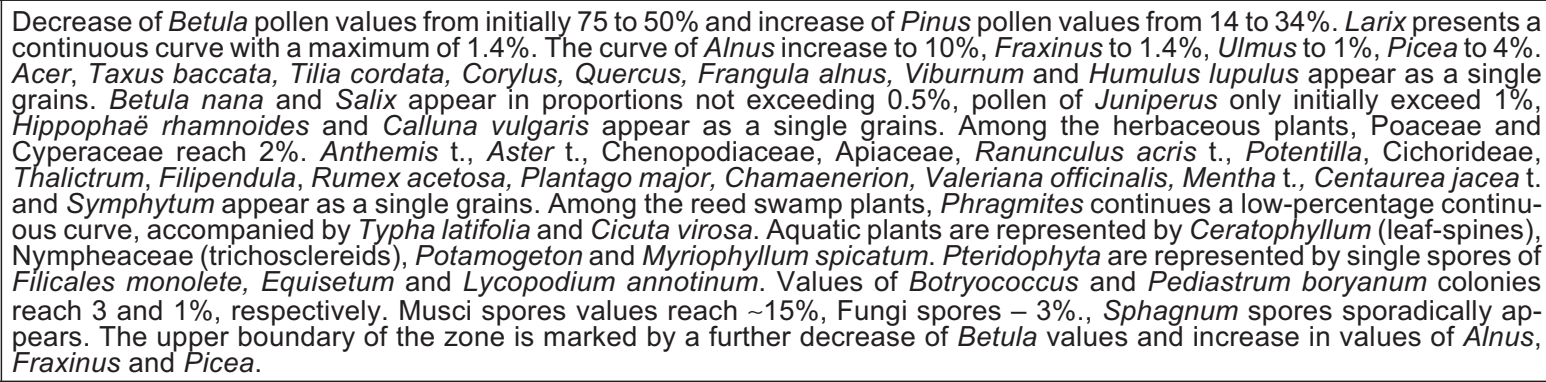 \\
\hline $\begin{array}{l}\frac{T}{\frac{1}{T}} \\
\frac{T}{I}\end{array}$ & 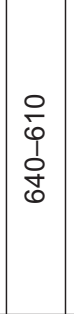 & & 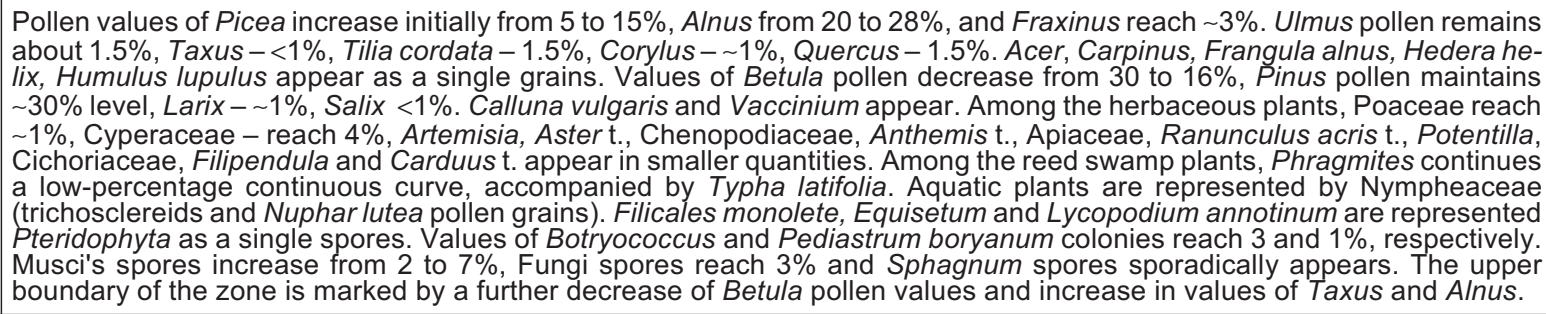 \\
\hline $\begin{array}{l}\frac{T}{1} \\
\frac{1}{T} \\
I\end{array}$ & $\begin{array}{l}\text { 웅 } \\
1 \\
1 \\
8 \\
0\end{array}$ & & $\begin{array}{l}\text { Picea curve reaches } 14 \% \text { level, Taxus baccata increase to } 12.5 \% \text { and Alnus to } 35 \% \text {. Fraxinus reach } 1.5 \% \text {, Ulmus - } 1 \% \text {, } \\
\text { Tilia cordata - } 1.5 \% \text {, Corylus - } 1.7 \% \text {, Quercus - } 2.8 \% \text {. Pinus pollen still maintains } \sim 30 \% \text { level, Betula decrease to } 5 \% \text {. Larix, } \\
\text { Acer, Carpinus, Abes and Hedera helix appear sporadically. Artemisia, Aster t., Poaceae, Cyperaceae, Chenopodiaceae, } \\
\text { Apiaceae, Caryophyllaceae and Cichorioideae appear in small quantities not exceeding } 1 \% \text {. Among the reed swamp plants } \\
\text { Phragmites continues a low-percentage continuous curve, accompanied by Cicuta virosa. Aquatic plants are represented by } \\
\text { Ceratophyllum (leaf-spines) and Nympheaceae (trichosclereids. Pteridophyta are represented by single spores of Filicales } \\
\text { monolete. Values of Botryococcus cenobia increase to almost } 5 \% \text {, and Pediastrum boryanum reach still } 1 \% \text {. Musci's spores } \\
\text { reach } 1 \% \text {, Fungi - above } 2 \% \text {, and Sphagnum }-<\% \text {. The upper boundary of the zone is marked by decrease of Taxus } \\
\text { baccata and Alnus pollen values and increase of Pinus pollen values. }\end{array}$ \\
\hline $\begin{array}{l}\frac{0}{1} \\
\frac{0}{T} \\
I\end{array}$ & $\begin{array}{l}0 \\
0 \\
10 \\
1 \\
0 \\
0 \\
10\end{array}$ & 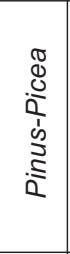 & 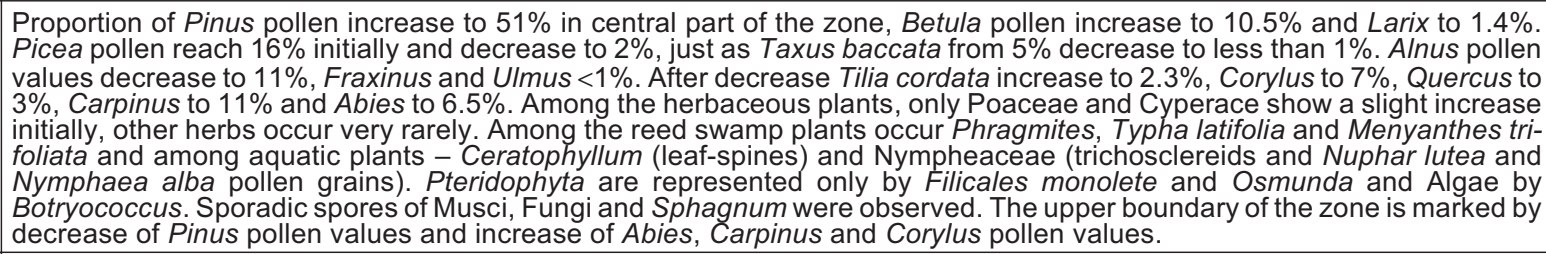 \\
\hline $\begin{array}{l}\varphi \\
\frac{1}{\omega} \\
I\end{array}$ & $\begin{array}{l}\text { O } \\
\text { L } \\
1 \\
0 \\
\text { மn } \\
⺊\end{array}$ & & 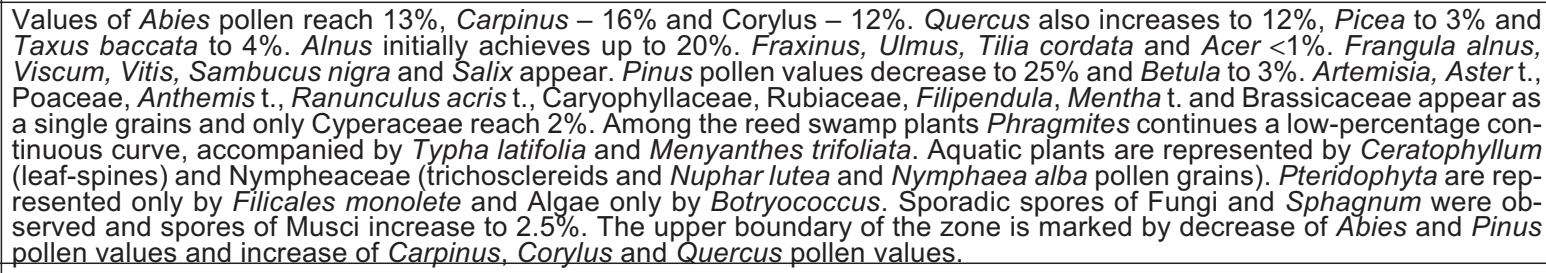 \\
\hline $\begin{array}{l}T \\
\frac{1}{\omega} \\
\frac{1}{T}\end{array}$ & $\begin{array}{l}0 \\
\text { 이 } \\
1 \\
0 \\
\text { గn }\end{array}$ & 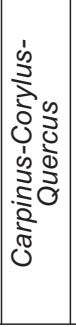 & 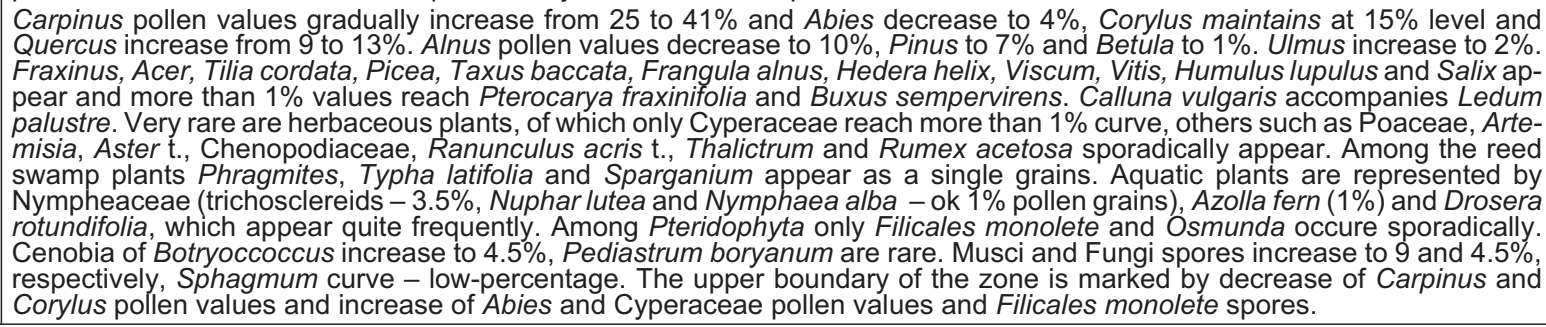 \\
\hline
\end{tabular}


Tab. 2 cont.

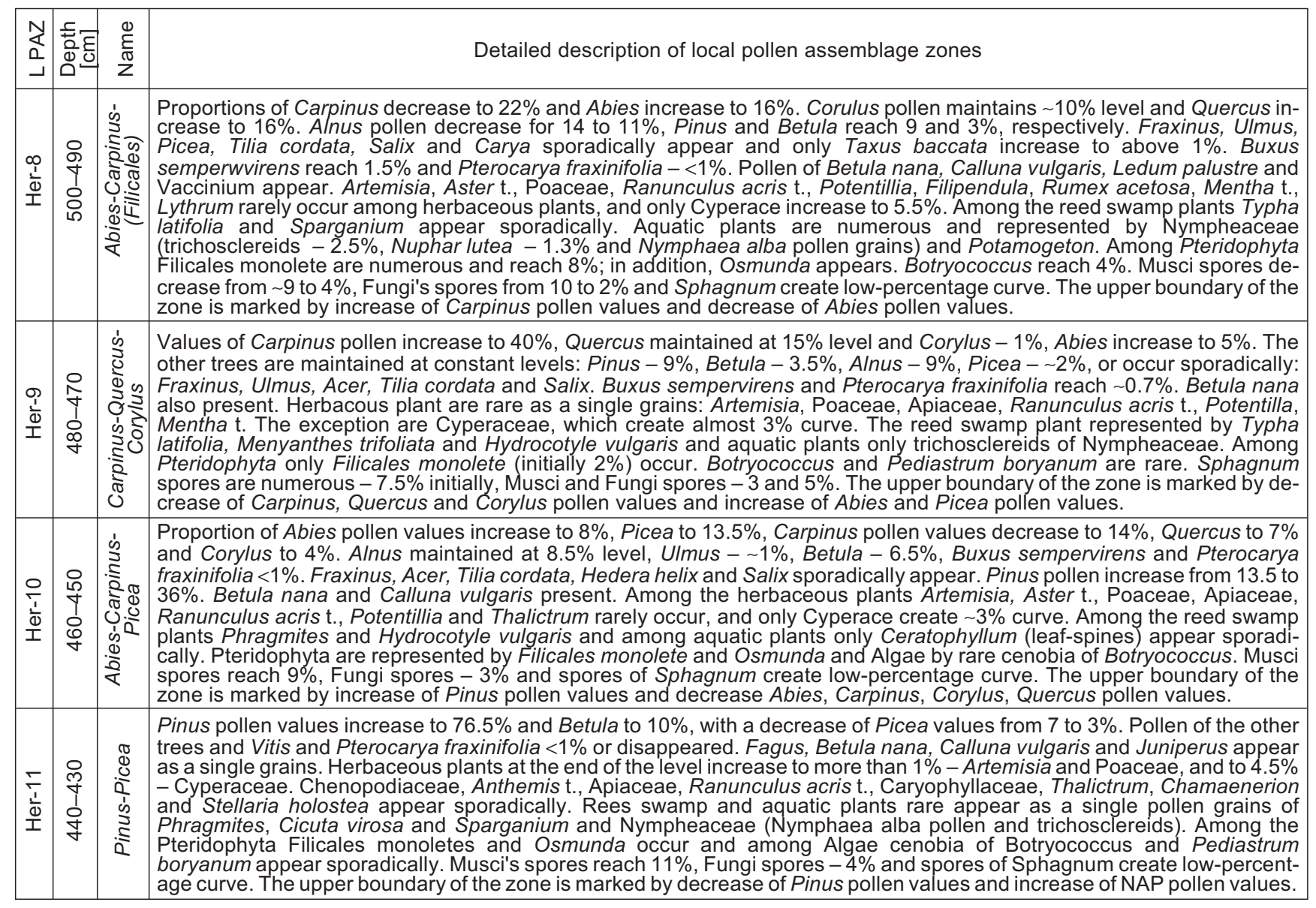

Table 3

Petrographic composition of gravels in the Hermanów profile

\begin{tabular}{|c|c|c|c|c|c|c|c|c|c|c|}
\hline \multirow{2}{*}{ Depth [m] } & \multicolumn{4}{|c|}{$\begin{array}{c}\text { Scandinavian rocks } \\
\text { (number of gravels) }\end{array}$} & \multicolumn{4}{c|}{$\begin{array}{c}\text { Local rocks } \\
\text { (number of gravels) }\end{array}$} \\
\cline { 2 - 12 } & $\mathrm{Cr}$ & $\mathrm{Lp}$ & $\mathrm{Dp}$ & $\mathrm{Sp}$ & $\mathrm{Qp}$ & $\mathrm{L}$ & $\mathrm{S}$ & $\mathrm{F}$ & $\mathrm{M}$ & $\mathrm{O}$ \\
\hline $2.0-4.0$ & 37 & - & 1 & 14 & 10 & - & - & - & - & 7 \\
\hline $4.0-6.0$ & 20 & 2 & - & 15 & 5 & - & - & 2 & - & 4 \\
\hline $8.0-10.0$ & 28 & 14 & 3 & 4 & 4 & 1 & 2 & 2 & 3 & - \\
\hline
\end{tabular}

$\mathrm{Cr}$ - crystalline rocks, $\mathrm{P}$ - Paleozoic rocks, $\mathrm{L}$ - limestone, $\mathrm{D}$ - dolomite, $\mathrm{S}$ - sandstone, $\mathrm{Q}$ - quartz, $\mathrm{F}$ - flint, $\mathrm{M}$ - mudstone, $\mathrm{O}$ - others

RESULTS OF ISOTOPE ANALYSIS AND ORGANIC MATTER CONTENT

Organic matter isotopic composition ranged from $-19.6 \%$ do $-32.2 \%$ o ${ }^{13} \mathrm{C}$ with average of $\delta^{13} \mathrm{C}=-27.6 \%$. The highest $\delta^{13} \mathrm{C}$ values were observed at $4 \mathrm{~m}$ depth $\left(\delta^{13} \mathrm{C}=-19.6 \%\right)$ and $5.6 \mathrm{~m}$ depth $\left(\delta^{13} \mathrm{C}=-20.4 \%\right.$ ). The lowest $\delta^{13} \mathrm{C}$ value $(-32.2 \%)$ was observed at the bottom of the profile. The content of organic matter in the profile ranged from 15 to almost $100 \%$. The analysed samples were represented by C3 plants.

\section{INTERPRETATION OF THE RESULTS AND DISCUSSION}

Lacustrine sediments of MIS 11 are very well preserved in the Hermanów palaeolake succession. The occurrence of lake sediments of the Mazovian/Holsteinian Interglacial in a palaeolake carved in glacial tills is an indirect proof of their age associated with the Elsterian Glaciation (Żarski, 2008, 2009). The results of petrographic analysis of glacial tills from the nearby 
Results of radiocarbon dating from the Hermanów profile

\begin{tabular}{|c|c|c|c|c|}
\hline Name of sample & $\begin{array}{l}\text { Laboratory } \\
\text { number }\end{array}$ & $\underset{[\mathrm{BP}]}{\mathrm{Age}}{ }^{14} \mathrm{C}$ & $\begin{array}{c}\text { Calendar age } \\
\text { (calibrated) } \\
\text { interval } 68.2 \% \text { [cal yr BP] }\end{array}$ & $\begin{array}{c}\text { Calendar age } \\
\text { (calibrated) } \\
\text { interval } 95.4 \% \text { [cal yr BP] }\end{array}$ \\
\hline Hermanów 3/0,8 & GdS-3449 & $4680 \pm 90$ & $\begin{array}{l}5580-5535(11.9 \%) \\
5480-5310(56.3 \%)\end{array}$ & $\begin{array}{l}5600-5265(88.3 \%) \\
5225-5215(0.2 \%) \\
5185-5060(7.0 \%)\end{array}$ \\
\hline
\end{tabular}

Domaszki site (Fig. 1; Terpiłowski et al., 2014) correlate the analysed glacial tills with the Elsterian Glaciation. The origin of the palaeolake is related to the melting of a dead-ice block of dimensions similar to the size of the present-day depression.

The pollen record of the Hermanów profile is typical for the Holsteinian/Mazovian Interglacial in central Europe with all its characteristic levels. The Hermanów profile does not include the Late Elsterian/Sanian 2 Glaciation.

In the first phase of palaeolake existence, silty sands passing into silts were accumulated during cold climate conditions. The Early Holsteinian/Mazovian Interglacial (Her-1 Betula; Table 2 and Fig. 5) in Hermanów is characterized by the total domination of bright, pioneer birch forests, with a significant representation of herbaceous vegetation. Increasing climate humidity coupled with its warming caused deposition of peats in the reservoir, which were transformed into peaty shales (from Her-2 to Her-4; Table 1 and Figs. 4, 5) as a result of subsequent post-sedimentary diagenetic processes. The birch-pine forests have developed extensively - Her-2 Betula-Pinus (Fig. 5).

Palynological records in the profile do not agree with the $\delta^{13} \mathrm{C}$ values of organic matter. When birch dominates (Her 1 and Her 2), the ${ }^{13} \mathrm{C}$ enrichment observed towards the top of the profile can be interpreted as a cooling period (Skrzypek et al., 2005; Fig. 8). The bottom of the profile is composed of silts derived from outside of the reservoir. Mineral sedimentation predominated in the palaeolake and most likely organic matter was redeposited together with silts. The organic matter content is relatively low (gradually increasing, but does not exceed $28 \%$; Fig. 8), which emphasizes also relatively low, but increasing temperatures at the time.

Then, along with increasingly humid climate, Picea and carr forests with Alnus and an admixture of Fraxinus and Ulmus spread out (Her-3 Picea-Alnus-Fraxinus; Table 2 and Fig. 5). Changes in the $\delta^{13} \mathrm{C}$ isotopic composition range $\sim 2 \%$ in this zone (enrichment in a heavy carbon isotope) and a small drop in organic matter content (to $22 \%$; Fig. 8 ) suggesting small temperature variations is possibly related to seasonal changes with warm and dry summers and cold and severe winters preferred by Picea (Zagwijn, 1996; Dahl, 1998). The mineral sedimentation was still dominant in the palaeolake.

The palynological record supports a gradual warming trend. The climate became more and more warm, humid and mild, similar to the oceanic climate, with an increase in groundwater level, which favoured the development of Picea-Taxus forest with a strong spread of the riparian Alnus representation (Her-4 Picea-Taxus-Alnus). In this zone we observe a gradual enrichment in the content of light carbon ( $\Delta$ more than $1.5 \%$ ) and organic matter (increasing rapidly to $43 \%$; Fig. 8 ).

The vegetation succession near Nowiny Żukowskie shows a similar development (Lublin Upland, Hrynowiecka-Czmielewska, 2010; Hrynowiecka and Winter, 2016), Brus (West Polesie, Pidek, 2003; Hrynowiecka and Pidek, 2017), and Ossówka sites (West Polesie, Krupiński, 1995; Nitychoruk et al., 2005). The succession is also similar to the Krzyżewo site
(NE Poland, Janczyk-Kopikowa, 1996), Lithuania (Kondratienè and Šeiriené, 2003), and Belarus (Rylova and Savchenko, 2005). To the west, the communities with Ulmus, Quercus and Corylus began to appear earlier, whereas Picea was less important, as evidenced by the Gajec site (W Poland, Winter and Urbański, 2007) and in Germany (Kühl and Litt, 2007).

The older regressive oscillation phase in the Holsteinian/Mazovian Interglacial (OHO; Koutsodendris et al., 2010) in the Hermanów profile is marked clearly in the peaty shales (Fig. 6). Climate continentalization was expressed by the increasing importance of Pinus and the collapse of Picea and the riparian Alnus and Taxus communities (Her-5 Pinus-Picea; Figs. 5, 6 and Table 2). More or less clearly, however, the OHO always appears similarly in the successions throughout Poland. The return of Pinus is often accompanied by the re-spread of Betula (Nowiny Żukowskie site, Hrynowiecka and Winter, 2016; Ossówka site, Krupiński, 1995; Nitychoruk et al., 2005), which is insignificant in the Hermanów profile. The OHO lasted about 220 years (Koutsodendris et al., 2012), but it spans up to $\sim 30 \mathrm{~cm}$ of the Hermanów profile. A similar situation is observed, e.g., in the Kaliłów profile in the Biała Podlaska area (Bińka and Nitychoruk, 1996). This may be due to the faster sedimentation rate at that time. It may have been caused by either increasing erosion associated with changes in the forest composition during this event or lowering of the palaeolake level. In both the previously analysed profiles from Poland and eastern Europe, the $\mathrm{OHO}$ has not been registered, due to the too low resolution of pollen analysis used at that time (Hrynowiecka and Winter, 2016). In turn, in Germany, the OHO is usually explicitly marked by the withdrawal of Taxus, Corylus and Quercus communities and the spread of Pinus-Betula forests (Koutsodendris et al., 2010).

Carbon isotopic records through the $\mathrm{OHO}(\mathrm{Her}-5)$ are characterized by ${ }^{13} \mathrm{C}$ enrichment close to $8 \%$ compared to Her-4. After initial warming during Her-4, rapid cooling occurred until the middle of the chronozone, followed by changes in climatic conditions to early Her-5 (Fig. 8). This is one of the coldest periods observed within the Hermanów profile. Despite the high cooling period, the accumulation of organic matter was quite high at a level of $40 \%$ (Fig. 8).

In the Hermanów profile, the next part of the Middle Phase of the Holsteinian Interglacial (Figs. 5 and 6 ) is characterized by a systematic increase of humidity in warm climate conditions, favouring the formation of poorly decomposed and non-decomposed peats under anaerobic conditions (Fig. 6). The development of maritime climate resulted in the development of forests with Abies and multi-species deciduous forests with Carpinus, Corylus and Quercus (Her-6 Abies-Carpinus-Corylus; Table 2 and Fig. 5). Riparian forests with Alnus and Taxus baccata returned and developed quite intensely. Later, the dominant role was taken over by Carpinus with an admixture of Corylus and Quercus (Her-7 Carpinus-Corylus-Quercus; Table 2 and Fig. 5). Thermophilic trees, i.e. Pterocarya fraxinifolia and Buxus sempervirens, appeared. Riparian forests subsided at 
that time. The proportion of trees differs in individual profiles from Poland; however, in general, the vegetation succession in this period developed similarly as presented above. Differences appear along the western - eastern European transect. In eastern Europe, the Middle Holsteinian/Mazovian Interglacial is characterized by the dominance of Picea and Abies forests and subsequently by Carpinus, Corylus and Quercus (Kondratienè and Šeiriené, 2003; Rylova and Savchenko, 2005). In western Europe, for example in Germany, Carpinus and Corylus dominate at that time, whereas Abies and Picea are of minor importance (Koutsodendris et al., 2010).

The younger regressive oscillation phase in the Middle Phase of Holsteinian/Mazovian Interglacial (YHO, Koutsodendris et al., 2010; Figs. 4 and 6) is marked quite clearly by poorly decomposed peat sediments (Table 1 and Fig. 6). It is characterized by the collapse of temperate deciduous mixed forests with Carpinus, Corylus and Quercus and the spread of Abies forests with a significant amount of Filicales monolete [Her-8 Abies-Carpinus-(Filicales); Table 2]. Taxa of pioneer trees and Cyperaceae show a slight increase, while the thermophilic taxa a slight decrease. The increase in Abies occurrence indicates the impact of oceanic/marine climate with a significant increase in humidity and possibly an increase in groundwater level, which is indicated by the appearance of significant amounts of Filicales and Cyperaceae. A very similar course of the $\mathrm{YHO}$ is observed in the Brus profile (Hrynowiecka and Pidek, 2017). It is also evident in the Nowiny Żukowskie site (Hrynowiecka and Winter, 2016), but in other profiles from Poland the succession is not clearly marked. The YHO is also poorly represented in eastern European profiles (Kondratiené and Šeirienè, 2003; Rylova and Savchenko, 2005). In western Europe, however, it is evident and characterized by a severe collapse of Carpinus and Picea and the spread of pioneer taxa - Pinus and Betula (Kühl and Litt, 2007; Koutsodendris et al., 2010). In the Hermanów profile, the YHO shows no fluctuations in the isotope record and organic matter content.

The youngest part of the Middle Phase of the Holsteinian Interglacial (still represented by poorly decomposed peat sediments; Fig. 6) is recorded by the withdrawal of Abies and the return of Carpinus, Quercus and Corylus broadleaved forests (Her-9 Carpinus-Quercus-Corylus), with a clear dominance of hornbeam, followed by coniferous forests with Abies, Picea and Pinus spread, whereas communities with Carpinus, Quercus and Corylus collapsed again (Her-10 Abies-Carpinus-Picea; Table 2 and Fig. 5). Riparian forests with Alnus, Fraxinus and Ulmus were in regression. However, Pterocarya fraxinifolia and Buxus sempervirens persisted.

Carbon isotopic composition of organic matter indicated that after cooling during the $\mathrm{OHO}$, climatic conditions stabilized. Chronozones Her- 6 and Her-10 have little changes in $\delta^{13} \mathrm{C}$ (less than 1\%; Fig. 8). Such small fluctuations of $\delta^{13} \mathrm{C}$ values can be interpreted as climate stabilization with seasonal temperature variation or minor cooling and warming episodes. Her- 6 and Her-10 are probably the warmest periods observed within the profile, which is confirmed by high content of organic matter: $67-97 \%$ (Fig. 8). The climate warming after the $\mathrm{OHO}$ was accompanied by slow growth of peat-forming vegetation interrupted by periods of low supply of sediments into the lake.

By the end of the Holsteinian/Mazovian Interglacial (Late Phase of MIS 11c), only Pinus and Picea communities persisted, whereas communities of thermophilic and riparian forests clearly collapsed (Her-11 Pinus-Picea; Table 2 and Fig. 5). More species of herbaceous plants appeared and the forests became sparse. The climate gradually became cooler and more continental. In general, such outline of changes is also observed in profiles from Poland. Very high proportions of Ptero- carya fraxinifolia pollen appear in some of them (Ossówka site, Krupiński, 1995; Nitychoruk et al., 2005). In others, Carpinus did not return after the regressive phase $(\mathrm{YHO}$, Koutsidendris et al., 2010) in such high proportions (Brus site, Hrynowiecka and Pidek, 2017). In western Poland (e.g., Gajec site, Winter and Urbański, 2007) and western Europe (Koutsodendris et al., 2010) it was Quercus and not Picea that played an important role at that time. In turn, in central France, Fagus occurs together with Abies (de Beaulieu et al., 2001). The organic matter content and carbon isotopic composition do not show any changes in this zone and even indicate stabilization of climate (Fig. 8).

The further part of MIS 11 in the Hermanów profile is characterized by a very strong decline in AP (1-st stadial, Her-12 NAP-Betula nana and Her-13 Cyperaceae-Poaceae-Betula nana; Table 2 and Figs. 6, 7), which most probably correlates with the cooling period MIS $11 \mathrm{~b}$, causing strong forest contractions in southern European records (i.a. Tzedakis et al., 2006). This phase is also considered the youngest part of MIS 11c (Oliveira et al., 2016; Kousis et al., 2018). At that time, trees withdrew and herbaceous plants dominated in the tundra communities, with Betula nana, numerous Musci and Cyperaceae, and grassland communities with Poaceae and Artemisia. Hydrological relations changed drastically at that time. At the beginning (Her-12), gyttja was accumulated in a deep, open water reservoir (Table 1 and Figs. 4, 6). Later on (Her-13), the groundwater level decreased, the lake became shallower (disappearance of Algae, poorly decomposed peat sediments) and overgrown with sedge rush (numerous Cyperaceae and related Gaeumannomyces hyphopodia), and flow processes intensified (numerous Fungi spores and wood vessel fragments).

Chronozones Her-12 and Her-13 are characterized by higher $13 \mathrm{C}$ enrichment of organic matter than that observed during Her-5, confirming the cooling trend. The difference in $\delta^{13} \mathrm{C}$ between Her- 6 - Her-10 is $\Delta 9 \%$ (Fig. 8). After climatic stabilization during Her-6 to Her-10, rapid cooling by several degrees followed, which is confirmed by palynological data. The cooling did not last very long and, at the end of Her-13, the climatic conditions returned to these existing before. During the period of significant cooling, the accumulation of organic matter disappears and inorganic sediment accumulation increased. The content of TOC drops to $20 \%$ (Fig. 8).

The long pollen records from southern Europe, e.g. the Lake Ohrid profile (Sadori et al., 2016; Kousis et al., 2018), show an increase in the value of Poaceae, Chenopodiaceae and Artemisia pollen in substage MIS 11b, and significant fluctuations in the value of tree pollen and constantly high proportions of Pinus pollen. Another long pollen record of MIS 11b from northwestern Iberian Margin Deep-Sea Cores (Desprat et al., 2007) also shows numerous fluctuations in the plant succession, which occurred including semidesert plants with grassland and heathland plants and temperate and humid forest trees phases including high proportions of Pinus.

Further changes in climatic conditions of the Hermanów area led to multiple successions of subsequent warming and cooling, but less pronounced than Her-12 and Her-13. All of them correspond to forest contractions during MIS 11a and should be correlated with this substage. The 1-st improving conditions (Her-14 Pinus) and the subsequent 2-nd, 3-rd and 4-th (Her-16 Pinus-NAP, Her-18 Pinus-NAP and Her-20 Pinus-NAP) are characterized by the return of pine forests, similar to Her-11 Pinus-Picea, with quite common herbaceous vegetation, however, with a much lower proportion of Picea (Table 2 and Figs. 5, 6). The 2-nd and 3-rd coolings (Her-15 Betula-NAP and Her-17 Betula-NAP) were dominated by sparse, luminous birch forests (perhaps a pioneer birch return 
phase in more severe conditions was already recorded here) and abundant herbaceous vegetation, as in the Brörup period (e.g., Granoszewski, 2003; Kołaczek et al., 2012). The subsequent 4-th and 5-th coolings (Her 19 NAP-Pinus-Betula and Her 21 NAP-Pinus) were characterized by slightly more pronounced climate changes. In the 4-th cooling, herbaceous plants already dominated, Pinus was more abundant, and Betula was less abundant than in the older cooling phases ( $\mathrm{Ta}-$ ble 2 and Figs. 6, 7). In turn, in the 5-th cooling, Betula hardly appears, but Pinus is quite numerous, although the condition of pollen preservation indicates long-distance transport.

The $\delta^{13} \mathrm{C}$ values indicate that after Her-13, climate conditions stabilized with little temperature changes (Fig. 8). An exception is early Her-16 with a drop in average temperature. Little changes in $\delta^{13} \mathrm{C}$ in the upper portion of the profile indicate stable temperatures and environment. The content of organic matter in this period was very diverse at $22-100 \%$ (Fig. 8), indicating fluctuating sediment input related to climate change. The sediments were formed under conditions of high water stand in a re-developed lake, in which peaty and laminated silts were accumulated. Further climate cooling resulted in the accumulation of silts and complete filling of the reservoir with sediments barren of pollen (Table 1 and Figs. 4, 6).

In Poland there are few sites with more than one cooling phase after MIS 11c (in older studies identified with the Early Liwiecian Glaciation = MIS 10); the Ossówka profile in the Biała Podlaska region is an exception (Krupiński, 1995; Nitychoruk et al., 2005). Here, three "interstadials" were recognized with a course similar to the 1-st and the subsequent coolings from the Hermanów profile. There are also four "stadials", which differ from the cooling phases recognized in the Hermanów profile mainly in the higher content of Juniperus pollen. However, none of the "stadials" from Ossówka show features of strong cooling typical of the MIS $11 \mathrm{~b}$ in Her-12 and Her-13.

The record of climate change and the vegetation succession in the Hermanów profile indicate that the MIS 11c, MIS 11b and Mls 11a substages can be distinguished in Poland based on pollen analysis. However, it should be remembered that the record is most probably incomplete, may contain gaps and an incomplete number of substages in the succession.

During the Early Liwiecian Glaciation (MIS 10, Fuhne Glaciation, Saalian Complex), most of Poland was not covered by an ice sheet (Lindner and Marks, 2012; Marks et al., 2018). A similar geological situation occurred in southwestern Poland and western Belarus (Marks et al., 2018). Sites with sediments of the Mazovian Interglacial without an ice sheet cover in western Podlasie confirm the hypothesis about the range of the Odra Glaciation (Saalian) ice sheet lobes (Marks et al., 2018). The area represented an interlobate zone. The eastern range zone of the Vistula lobe during the Odra Glaciation was located more than a dozen kilometres from the Hermanów site (Fig. 1).

There is a large hiatus encompassing the MIS 10 to MIS 3 interval in the geological record of the Hermanów profile. Filling of the reservoir with lake sediments resulted in the disappearance of the depression, where further accumulation of younger sediments was not possible. During the Saalian Complex (MIS 8, 6 and 4), permafrost was permanent in the study area; it contributed to the preservation of the lake sediments in Hermanów (Błaszkiewicz, 2011). Compaction of deposits in the Vistulian contributed to lowering of the terrain by about $0.5 \mathrm{~m}$ and the appearance of a periodic water reservoir, in which silty sands and sandy silts were accumulated. This period may be correlated with MIS 2 (Table 1 and Fig. 4).
The composition of heavy minerals with the dominance of weathering-resistant ones suggests a multiple deposition of sediments, including in aeolian and aquatic environments. The low content of calcium carbonate confirms the thesis about the destruction of carbonates in these environments. These are the features of deluvial sediments that got into the water reservoir during the cold period of the Vistula Glaciation. Another possibility is that there were no limestone rocks in the source area (have been destroyed by weathering processes), and no import of detrital carbonates.

OSL studies of deposits occurring above the lake sediments of MIS 11 in four sites in the eastern Podlasie region have shown ages from 16 to $12 \mathrm{ka}$ (Marks et al., 2018). It seems very likely that these sediments represent a similar age in the Hermanów profile. Filling of the depression in MIS 2 caused another sediment hiatus in the geological record. Further compaction of lake sediments (by about $1 \mathrm{~m}$ ) resulted in the repeated formation of a closed depression. Within this depression, a shallow lake was formed, where clayey peat and peat accumulated in a humid and warm climate. The calendar age of the sample taken from the base of the Holocene peat from a depth of $0.7 \mathrm{~m}$ is $5600-5265$ years cal BP (Michczyński, 2017) and correlates with the Subboreal Period of the Holocene (Ralska-Jasiewiczowa et al., 1998). Probable lowering of the water level in the Subboreal period (Holocene) caused shallowing of the lake and accumulation of silty sands from the reservoir surroundings. Climate warming and increased precipitation in the Subatlantic Period resulted in bog formation and accumulation of non-decomposed peats (Fig. 6).

\section{CONCLUSIONS}

The geological, isotope and palaeoenvironmental research of sediments from the Hermanów profile and numerous neighbouring sections indicate the existence of a large Mazovian palaeolakeland in this area.

The palaeolake from the Mazovian Interglacial period (MIS 11c) at the Hermanów site and the palaeolake in the neighbouring sites have a post-glacial genesis and are associated with the melting of a dead-ice block at the end of the Elsterian Glaciation. The lake basins were carved in glacial tills of this glaciation. The petrographic composition of gravels found in these tills is characteristic of the Elsterian tills from the research area. The geological research allowed documenting a palaeolakeland from the Mazovian Interglacial period in this area, which was created at the same time and under the same conditions during the Late Elsterian deglaciation.

Records of climatic and environmental changes during the Mazovian/Holsteinian Interglacial (MIS 11c) from the Hermanów profile (SE Poland) allows distinguishing three phases: Early, Middle (including the $\mathrm{OHO}$ and $\mathrm{YHO}$ ), and Late. The Early Phase indicates the improvement of climatic conditions after the glacial period and a continuous and slight temperature rise recorded in pioneering birch forests. The Middle Phase is a consequent improvement of climatic conditions and increasing temperature with an expansion of spruce-yew thermophilic forests. The $\mathrm{OHO}$ is a strong regressive climatic phase leading to the withdrawal of thermophilic communities and the spread of pioneering pine forests. The next period of the Middle Phase is characterized by the relative balance of the climax broadleaved hornbeam-oak-hazel forests with fir admixture. The YHO phase in eastern Poland is a lower rank regressive change, leading to increasing influence of maritime 
climate and collapse, but not complete withdrawal, of deciduous forest communities. The rest of the Middle Phase is characterized by the dominance of broadleaved forests with fir and spruce. During the Late Phase, gradual deterioration of climatic conditions occurred, which led to the spread of boreal pine forests.

The strong decline of forests (AP) with very severe climatic conditions in the further part of the profile corresponds to the MIS $11 \mathrm{~b}$ cooling. Further changes led to multiple alternating improvement and cooling (with forest contractions) of climatic conditions, which may correspond to the MIS 11a substage.

TOC and carbon isotopic composition analysis $\left(\delta^{13} \mathrm{C}\right)$ adds value to the palaeoenvironmental reconstructions and often support geological and environmental analyses. The data confirm strong cooling in the $\mathrm{OHO}$ and MIS $11 \mathrm{~b}$ and do not show variability during $\mathrm{YHO}$, which may suggest other reasons for this oscillation. An alternative explanation may be that samples were analysed with too low resolution for the short-lived palaeo- climatic events. There is, however, a discrepancy in the correlation between isotopic and palynological studies. Most likely, it results from slower changes in terrestrial flora compared to peat-growing plants, fast reacting to environmental changes recorded by the $\delta^{13} \mathrm{C}$ values. Another factor influencing the discrepancy could be the influx of organic matter from outside of the palaeolake, redeposited within the reservoir altering the palaeoenvironmental record.

Acknowledgements. The authors would like to thank the Polish Geological Institute - National Research Institute for the possibility of implementing the research task, the results of which are presented in this article. We thank B. Marcinkowski, for performing lithological-petrographic analysis (PIG-PIB), I. Matejko, for the preparation of palynological samples (PIG-PIB), and W. Żarski, for taking a photo of the Hermanów site using a drone. We also thank the Reviewers for valuable substantive comments.

\section{REFERENCES}

Albrycht, A., Bińka, K., Brzezina, R., Dyjor, K., Nitychoruk, J., Pavlovskaya, I., 1997. Uwagi o nowych stanowiskach osadów interglacjalnych na tle stratygrafii młodszego czwartorzędu południowego Podlasia (in Polish). Przegląd Geologiczny, 6: 629-633.

Ashton, N.M. 2010. Challenges to the Occupation of North-West Europe during the Late Middle Pleistocene. Ph.D. thesis, University of Leiden.

Ashton, N.M, Lewis, S.G., Parfitt, S.A., Penkman, K.E.H., Coope., G.R., 2008. New evidence for complex climate change in MIS 11 from Hoxne, Suffolk, UK. Quaternary Science Reviews, 27: 652-668.

Bazin, L., Landais, A., Lemieux-Dudon, B., Kele, H.T.M., Veres, D., Parrenin, F., Martinerie, P., Ritz, C., Capron, E., Lipenkov, V., Loutre, M.F., Raynaud, D., Vinther, B., Svensson, A., Rasmussen, S.O., Severi, M., Blunier, T., Leuenberger, M., Fischer, H., Masson-Delmotte, V., Chappellaz, J., Wolff, E., 2013. An optimized multi-proxy, multi-site Antarctic ice and gas orbital chronology (AICC2012): 120-800 ka. Climate of the Past, 9: 1715-1731.

Berglund, B.E., Ralska-Jasiewiczowa, M., 1986. Pollen analysis and pollen diagrams. In: Handbook of Holocene Palaeoecology and Palaeohydrology (eds. B.E. Berglund and M. Ralska-Jasiewiczowa): 455-484. John Wiley and Sons Ltd., Chichester, New York.

Bińka, K., Marks L., 2018. Terrestrial versus marine archives: biostratigraphical correlation of the Middle Pleistocene lacustrine records from central Europe and their equivalents in the deep-sea cores from the Portuguese margin. Geological Quarterly, 62 (1): 69-80.

Bińka, K., Nitychoruk, J., 1995. Mazovian (Holsteinian) lake sediments at Woskrzenice near Biała Podlaska. Geological Quarterly, 39 (1): 109-120.

Bińka, K., Nitychoruk, J., 1996. Geological and palaeobotanical setting of interglacial sediments at the Kaliłów site in southern Podlasie. Geological Quarterly, 40 (2): 269-282.

Błaszkiewicz, M., 2011. Timing of the final disappearance of permafrost in the Central European Lowland as reconstructed from the evolution of lakes in N Poland. Geological Quarterly, 55 (4): 361-374.

Börner, A., 2007. Comparison of Quaternary stratigraphy used in Northeast-Germany and Poland. Brandenburgische Geowissenschaftliche Beiträge, 14: 15-24.
Bronk Ramsey, C., Dee, M., Lee, S., Nakagawa, T., Staff, R., 2010. Developments in the calibration and modelling of radiocarbon dates. Radiocarbon, 52: 953-961.

Cohen, K.M., Gibbard, P.L., 2011. Global chronostratigraphical correlation table for the last 2.7 million years v. 2011. http://quaternary.stratigraphy.org/wp-content/uploads/2018/04/POSTERstratchart-v2011.jpg

Coletti, A.J., DeConto, R.M., Brigham-Grette, J., Melles, M., 2015. A GCM comparison of Pleistocene super-interglacial periods in relation to Lake El'gygytgyn, NE Arctic Russia. Climate of the Past, 11: 979-989.

Dahl, E., 1998. The Phytogeography of Northern Europe (British Isles, Fennoscandia and Adjacent Areas). Cambridge University Press, UK.

Desprat, S., Sanchez Goñi, M.F., Naughton, F., Turon, J.-L., Duprat, J., Malaizé, B., Cortijo, E., Peypouquet, J.-P., 2007. Climate variability of the last five isotopic interglacials: direct land-sea-ice correlation from the multiproxy analysis of North-Western Iberian margin deep-sea cores. Developments in Quaternary Science, 7: 375-386.

de Abreu, C., Abrantes, F.F., Shackleton, N.J., Tzedakis, P.C., McManus, J.F., Oppo, D.W., Hall, M.A., 2005. Ocean climate variability in the eastern North Atlantic during interglacial marine isotope stage 11: a partial analogue to the Holocene? Paleoceanography, 20: PA3009.

de Beaulieu, J.-L., Andrieu-Ponel, V., Reille, M., Gruger, E., Tzedakis, C., Svobodova, H., 2001. An attempt at correlation between the Velay pollen sequence and the Middle Pleistocene stratigraphy from central Europe. Quaternary Science Reviews, 20: 1593-1602.

Erdtman, G., 1960. The acetolysis method. Svensk Botanisk Tidskrift, 54: 561-564.

Fawcett, P.J., Werne, J.P., Anderson, R.S., Heikoop, J.M., Brown, E.T., Berke, M.A., Smith, S.J., Goff, F., Donohoo-Hurley, L., Cisneros-Dozal, L.M., Schouten, S., Sinninghe Damsté, J.S., Huang, Y., Toney, J., Fessenden, J., WoldeGabriel, G., Atudorei, V., Geissman, J.W., Allen, C.D., 2011. Extended megadroughts in the southwestern United States during Pleistocene interglacials. Nature, 470: 518-521.

Folk, R.L., Ward W.L., 1957. Brazos River bar: a study in the significance of grain size parameters. Journal of Sedimentary Research, 27: 3-26. 
Gale, S.J., Hoare, P.G., 1991. Quaternary Sediments: Petrographic Methods for the Study of Unlithified rocks. Belhaven Press, London.

Geyh, M.A., Müller, H., 2005. Numerical 230Th/U dating and a palynological review of the Holsteinian/Hoxnian interglacial. Quaternary Science Reviews, 24: 1861-1872.

Goździk J., 1981. Les changements de processus éoliens dans la Pologne Centrale au cours du Vistulien (Würm). Recherches géographiques a Strasbourg, 16-17: 115-120.

Gradziński, R., Kostecka, A., Radomski, A., Unrung, R., 1986 Zarys sedymentologii (in Polish). Wydawnictwo Geologiczne, Warszawa.

Granoszewski, W., 2003. Late Pleistocene vegetation history and climatic changes at Horoszki Duże, Eastern Poland: a palaeobotanical study. Acta Palaeobotanica, 4: 3-95.

Howard, W.R., 1997. A warm future in the past. Nature, 388: 418-419.

Hrynowiecka, A., Pidek, I.A., 2017. Older and Younger Holsteinian climate oscillations in the palaeobotanical record of the Brus profile (SE Poland). Geological Quarterly, 61 (4): 723-737.

Hrynowiecka, A., Winter, H., 2016. Palaeoclimatic changes in the Holsteinian Interglacial (middle Pleistocene) on the basis of indicator-species method - palynological and macrofossils remains from Nowiny Żukowskie site (SE Poland). Quaternary International, 409: 255-269.

Hrynowiecka, A., Żarski, M., Winter, H., 2014. Vegetation and stratigraphy of the Mazovian (Holsteinian) Interglacial sections from Dobropol and other new sites in Western Polesie Region, South-Easten Poland. Studia Quaternaria, 31: 17-30.

Hrynowiecka-Czmielewska, A., 2010. History of vegetation and climate of the Mazovian (Holsteinian) Interglacial and the Liviecian (Saalian) Glaciation on the basis of pollen analysis of palaeolake sediments from Nowiny Żukowskie, SE Poland. Acta Palaeobotanica, 5: 17-54.

Janczyk-Kopikowa, Z., 1996. Temperate stages of the Mesopleistocene in NE Poland (in Polish with English summary). Biuletyn Państwowego Instytutu Geologicznego, 373: 49-66.

Jęczmyk M., Kanasiewicz J., 1970. Mineral composition of alluivial deposits in the Kwisa River valley, Leśna region (in Polish with english summary). Kwartalnik Geologiczny, 14 (3): 549-560.

Jouzel, J., Masson-Delmotte, V., Cattani, O., Dreyfus, G., Falourd, S., Hoffmann, G., Minster, B., Nouet, J., Barnola, J.M., Chappellaz, J., Fischer, H., Gallet, J.C., Johnsen, S., Leuenberger, M., Loulergue, L., Luethi, D., Oerter, H., Parrenin, F., Raisbeck, G., Raynaud, D., Schilt, A., Schwander, J., Selmo, E., Souchez, R., Spahni, R., Stauffer, B., Steffensen, J.P., Stenni, B., Stocker, T.F., Tison, J.L., Werner, M., Wolff, E.W., 2007. Orbital and millennial Antarctic climate variability over the past 800,000 years. Science, 317: 793-796.

Kenig, K., 1998. Petrograficzne podstawy stratygrafii glin morenowych Polski północno-wschodniej (in Polish). Biuletyn Państwowego Instytutu Geologicznego, 380: 1-99.

Klein, C., Hurlbut, C.S., 1993. Manual of Mineralogy. Wiley, New York.

Kleinen, T., Hildebrandt, S., Prange, M., Rachmayani, R., Müller, S., Bezrukova, E., Brovkin, V., Tarasov, P.E., 2014. The climate and vegetation of Marine Isotope Stage 11e. Model results and proxy-based reconstructions at global and regional scale. Quaternary International, 348: 247-265.

Kołaczek, P., Karpińnska-Kołaczek, M.J., Petera-Zganiacz, J., 2012. Vegetation patterns under climate changes in the Eemian and Early Weichselian in Central Europe inferred from a palynological sequence from Ustków (central Poland). Quaternary International, 268: 9-20.

Kondracki, J., 2002. Geografia fizyczna Polski (in Polish). PWN, Warszawa.

Kondratienè, O., Šeirienè, V., 2003. Vegetation and climate of the Butenai Interglacial (Holsteinian) in Lithuania. Geological Quarterly, 47 (2): 139-148.

Kousis, I., Koutsodendris, A., Peyron, O., Leicher, N., Francke, A., Wagner, B., Giaccio, B., Knipping, M., Pross, J., 2018. Centennial-scale vegetation dynamics and climate variability in
SE Europe during Marine Isotope Stage 11 based on a pollen record from Lake Ohrid. Quaternary Science Reviews, 190: 20-38.

Koutsodendris, A., Müller, U.C., Pross, J., Brauer, A., Kotthoff, U., Lotter, A.F., 2010. Vegetation dynamics and climate variability during the Holsteinian interglacial based on a pollen record from Dethlingen (northern Germany). Quaternary Science Reviews, 29: 3298-3307.

Koutsodendris, A., Pross, J., Müller, U.C., Brauer, A., Fletcher, W.J., Kühl, N., Kirilova, E., Verhagen, F.T.M., Lücke, A., Lotter, A.F., 2012. A short-term climate oscillation during the Holsteinian interglacial (MIS 11c): an analogy to the 8.2 ka climatic event? Global and Planetary Change, 92/93: 224-235.

Koutsodendris, A., Pross, J., Zahn, R., 2014. Exceptional Agulhas leakage prolonged interglacial warmth during MIS $11 \mathrm{c}$ in Europe. Paleoceanography, 29: 1062-1071.

Krupiński, K.M., 1995. Wapienne osady jeziorne interglacjału mazowieckiego i wczesnego glacjału w Ossówce na Podlasiu (in Polish). Przeglad Geologiczny, 43: 117-122.

Krupiński, K.M., 2000. Palynostratigraphic correlation of deposits of the Mazovian Interglacial of Poland. Prace Państwowego Instytutu Geologicznego, 169: 1-61.

Krupiński, K.M., 2004. Opracowanie paleobotaniczne profilu Hermanów. Supplementary materials (in Polish). In: Szczegółowa Mapa Geologiczna Polski 1:50 000, ark. Adamów WG (ed. M. Żarski). Państwowy Instytut Geologiczny, Warszawa.

Krupiński, K.M., 2009. Badania paleobotaniczne osadów biogenicznych z Hermanowa (in Polish). In: XVI Konferencja Stratygrafia Plejstocenu Polski. Strefa marginalna zlodowacenia warty i pojezierza plejstoceńskie na południowym Podlasiu (eds. M., Żarski and S. Lisicki): 185-188. Zimna Woda k. Łukowa, 31.08-4.09.

Krygowski B., 1956. Glanurometric investigations on the Pleistocene of Western Poland (in Polish with English summary) Biuletyn Instytutu Geologicznego, 100: 503-608.

Krygowski B., 1967. Zmienność glin morenowych w zakresie uproszczonego składu petrograficznego (in Polish). Zeszyty Naukowe UAM, Geografia 7, 59-65.

Kühl, N., Litt, T., 2007. Quantitative time-series reconstructions of Holsteinian and Eemian temperatures using botanical data. The climate of the past interglacials. In: Developments in Quaternary Science, vol. 7 (eds. F. Sirocko and M. Claussen, M.F. Sánchez-Goñi and T. Litt): 239-254. Elsevier, Amsterdam, Oxford.

Lajtha, K., Marshal, J.D., 1994. Sources of variation in the stable isotopic composition of plants. In: Stable Isotopes in Ecology and Environmental Sciences (eds. K. Lajtha and R.H. Michener): 1-21. Blackwell Scientific Publication.

Lauterbach, S., Brauer, A., Litt, T., Schettler, G., 2012. Re-evaluation of the Bispingen palaeolake record - a revised chronology for the Eemian in Northern Germany. Geophysical Research Abstracts, Vol. 14, EGU2012-8613. General Assembly European Geosciences Union (Vienna, Austria).

Lindner, L., Marks, L., 1999. New approach to stratigraphy of palaeolake and glacial sediments of the younger Middle Pleistocene in mid-eastern Poland. Geological Quarterly, 43 (1): 1-8.

Lindner, L., Marks, L., 2012. Climatostratigraphic subdivision of the Pleistocene Middle Polish Complex in Poland (in Polish with English summary). Przegląd Geologiczny, 60: 36-45.

Lindner, L., Bogutsky, A., Gozhik, P., Marks, L., Łanczont, M., Wojtanowicz, L., 2006. Correlation of Pleistocene deposits in the area between the Baltic and Black Sea, Central Europe. Geological Quarterly, 50 (1): 195-210.

Lindner, L., Bogucki, A., Chlebowski, R., Gożik, P., Jełowiczewa, J., Wojtanowicz, J., Zaleski, I., 2007. Quaternary stratigraphy in the Volhynian Polesie (NW Ukraine). Annales Universitatis Mariae Curie-Skłodowska, 62: 7-37.

Lipp, J., Trimborn, P., Fritz, P., Moser, H., Becker, B., Frenzel, B., 1991. Stable isotopes in tree ring cellulose and climate change. Tellus, 43B: 322-330.

Lisicki, S., 2003. Litotypy i litostratygrafia glin lodowcowych plejstocenu dorzecza Wisły (in Polish). Prace Państwowego Instytutu Geologicznego, 177: 1-105. 
Lisiecki, L.E., Raymo, M.E., 2005. A Pliocene-Pleistocene stack of 57 globally distributed benthic $\delta^{18} \mathrm{O}$ records. Paleoceanography, 20: PA1003.

Małek, M., 2008. Objaśnienia tekstowe do Szczegółowej Mapy Geologicznej Polski w skali 1:50 000 ark. Łuków (in Polish). Wydawnictwa Geologiczne, Warszawa.

Małek, M., Pidek, I.A., 2007. Palynostratigraphy of organic deposits of new interglacial stands of Łuków Plain. Annales Universitatis Mariae Curie-Skłodowska, 62: 43-57.

Marcinkowski, B., Mycielska-Dowgiałło, E., 2013. Heavy minerals analysis in Poland investigations of Quaternary deposits: a review. Geologos, 19: 5-23.

Marks, L., 2004. Pleistocene glacial limits in Poland. In: Quaternary Glaciations - Extent and Chronology (eds. J. Ehlers and P.L. Gibbard): 295-300. Quaternary Glaciations - Extent and Chronology. Elsevier, Amsterdam-Boston.

Marks, L., Dzierżek, J., Janiszewski, R., Kaczorowski, J., Lindner, L., Majecka, A., Makos, M., Szymanek, M., Tołoczko-Pasek, A., Woronko, B., 2016. Quaternary stratigraphy and palaeogeography of Poland. Acta Geologica Polonica, 66: 403-427.

Marks, L., Karabanov, A., Nitychoruk, J., Bahdasarau, M., Krzywicki, T., Majecka, A., Pochocka-Szwarc, K., Rychel, J., Woronko, B., Zbucki, Ł., Hradunova, A., Hrychanik, M., Mamchyk, S., Rylova, T., Nowacki, Ł., Pielach, M., 2018. Revised limit of the Saalian ice sheet in central Europe. Quaternary International, 478: 59-74.

Melles, M., Brigham-Grette, J., Minyuk, P.S., Nowaczyk, N.R., Wennrich, V., DeConto, R.M., Anderson, P.M., Andreev, A.A., Coletti, A., Cook, T.L., Haltia-Hovi, E., Kukkonen, M., Lozhkin, A.V., Rosén, P., Tarasov, P., Vogel, H., Wagner, B., 2012. 2.8 Million Years of Arctic Climate Change from Lake El'gygytgyn, NE Russia. SCIENCE. Science, 337(6092): 315-320.

Michczyński, A., 2017. Wyniki oznaczenia wieku bezwzględnego metodą radiowęglową próbki torfów ze stanowiska Hermanówmanuskrypt (in Polish). Archiwum NAG, Państwowy Instytut Geologiczny.

Moncel, M.-H., Arzarello, M., Peretto, C., 2016. The Holsteinian period in Europe (MIS 11-9). Quaternary International, 409: 1-8.

Müller, H., 1974. Pollenanalytische Untersuchungen und Jahresschichtenzählungen an der Eem-zeitlichen Kieselgur von Bispingen/Luhe. Geologisches Jahrbuch, A 21: 149-168.

Mycielska-Dowgiałło, E., Rutkowski, J., 1995. Badania osadów czwartorzędowych, wybrane metody i interpretacja wyników (in Polish). Wydział Geografii i Studiów Regionalnych Uniwersytetu Warszawskiego.

Myślińska, E., 2016. Laboratoryjne badania gruntów i gleb (in Polish). Wydawnictwo Uniwersytetu Warszawskiego.

Nalepka, D., Walanus, A., 2003. Data processing in pollen analysis. Acta Palaeobotanica, 43: 125-134.

Nitychoruk, J., 1994. Stratygrafia plejstocenu i paleogeomorfologia południowego Podlasia (in Polish). Rocznik Międzyrzecki, 26: 23-107.

Nitychoruk, J., 2000. Climate reconstruction from stable-isotope composition of the Mazovian Interglacial (Holsteinian) lake sediments in eastern Poland. Acta Geologica Polonica, 50: 247-294.

Nitychoruk, J., Bińka, K., Hoefs, J., Ruppert, H., Schneider, J., 2005. Climate reconstruction for the Holsteinian Interglacial in eastern Poland and its comparison with isotopic data from Marine Isotope Stage 11. Quaternary Science Reviews, 24: 631-644.

Nitychoruk, J., Bińka, K., Ruppert, H., Schneider, J., 2006. Holsteinian Interglacial - marine isotope stage 11? Quaternary Science Reviews, 25: 2678-2681.

O'Leary, M.H., 1981. Carbon isotope fractionation in plants. Phytochemistry, 20: 553-567.

Oliveira, D., Desprat, S., Rodrigues, T., Naughton, F., Hodell, D., Trigo, R., Rufino, M., Lopes, C., Abrantes, F., Sanchez Goñi, M.F., 2016. The complexity of millennial-scale variability in southwestern Europe during MIS 11. Quaternary Research, 86: 373-387.

Parrenin, F., Barnola, J.-M., Beer, J., Blunier, T., Castellano, E., Chappellaz, J., Dreyfus, G., Fischer, H., Fujita, S., Jouzel, J.,
Kawamura, K., Lemieux-Dudon, B., Loulergue, L., Masson-Delmotte, V., Narcisi, B., Petit, J.-R., Raisbeck, G., Raynaud, D., Ruth, U., Schwander, J., Severi, M., Spahni, R., Steffensen, J.P., Svensson, A., Udisti, R., Waelbroeck, C., Wolff, E., 2007. The EDC3 chronology for the EPICA Dome C ice core. Climate of the Past, 3: 485-497.

Paul, D., Skrzypek, G., Forizs, I., 2007. Normalization of measured stable isotope composition to isotope reference scale - a review. Rapid Commun Mass Spectrom, 21: 3006-3014.

Pidek, I.A., 2003. Mesopleistocene vegetation history in the northern foreland of the Lublin Upland based on palaeobotanical studies of the profiles from Zdany and Brus sites. Maria Curie-Skłodowska University Press, Lublin.

Pidek, I.A., Terpiłowski, S., Małek, M., 2011. Succession of the Mazovian Interglacial near Łuków (E. Poland): palynostratigraphic and palaeogeographic approach. Geologija, 53: 27-35.

Prokopenko, A.A., Karabanov, E.B., Williams, D.F., Kuzmin, M.I., Shackleton, N.J., Crowhurst, S.J., Peck, A., Gvozdkov, A.N., King, J.W., 2001. Biogenic silica record of the Lake Baikal response to climatic forcing during the Bruhnes. Quaternary Research, 55: 123-132.

Racinowski, R., 1995. Analiza minerałów ciężkich w badaniach osadów czwartorzędowych Polski. Wybrane metody i interpretacji wyników (in Polish). In: Badania osadów czwartorzędowych (eds. E. Mycielska-Dowgiałło and J. Rutkowski): 151-175. Komisja Litologii i Genezy Osadów Czwartorzdowych PAN. UW i Państwowy Instytut Geologiczny, Warszawa.

Railsback, L.B., Gibbard, P.L., Head, M.J., Voarintsoa, N., Toucanne, S., 2015. An optimized scheme of lettered marine isotope substages for the last 1.0 million years, and the climatostratigraphic nature of isotope stages and substages. Quaternary Science Reviews, 111: 94-106.

Ralska-Jasiewiczowa, M., Goslar, T., Madeyska, T., Starkel, L., 1998. Lake Gościąż, Central Poland. A monographic study. Part 1. W Shafer Institute of Botany Polish Academy of Sciences, Kraków.

Raymo, M.E., Mitrovica, J.X., 2012. Collapse of polar ice sheets during the stage 11 interglacial. Nature, 483(7390): 453-456.

Reille, M., de Beaulieu, J.-L., Svobodova, H., Andrieu-Ponel, V., Goeury, C., 2000. Pollen stratigraphy of the five last climatic cycles in a long continental sequences from Valey (Massif Central, France). Journal of Quaternary Science, 15: 665-685.

Reimer, P.J., Bard, E., Bayliss, A., Beck, J.W., Blackwell, P.G., Bronk Ramsey, Buck, C.E., Cheng, H., Edwards, R.L., Friedrich, M., Grootes, P.M., Guilderson, T.P., Haflidason, H., Hajdas, I., Hatté, C., Heaton, T.J., Hoffmann, D.L., Hogg, A.G., Hughen, K.A., Kaiser, K.F., Kromer, B., Manning, S.W., Niu, M., Reimer, R.W., Richards, D.A., Scott, E.M., Southon, J.R., Staff, R.A., Turney, C.S.M., van der Plicht, J., 2013. IntCal13 and Marine13 Radiocarbon Age Calibration Curves 0-50,000 Years cal BP. Radiocarbon, 55: 1869-1887.

Reyes, A.V., Carlson, A.E., Beard, B.L., Hatfield, R.G., Stoner, J.S., Winsor, K., Welke, B., Ullman, D.J., 2014. South Greenland ice-sheet collapse during Marine Isotope Stage 11. Nature, 510: 525-528.

Rodrigues, T, Voelker, A.H.L., Grimalt, J.O., Abrantes, F., Naughton, F., 2011. Iberian Margin sea surface temperature during MIS 15 to 9 (580-300 ka): Glacial suborbital variability versus interglacial stability. Paleoceanography, 26: PA1204.

Rohling, E.J., Braun, K., Grant, K., Kucera, M., Roberts, A.P., Siddal, M., Trommer, G., 2010. Comparison between Holocene and Marine Isotope Stage - 11 sea-level histories. Earth and Planetary Science Letters, 291: 97-105.

Rylova, T., Savchenko, I., 2005. Reconstruction of palaeotemperatures of Pleistocene interglacial intervals of Belarus from palynological evidences. Polish Geological Institute Special Papers, 16: 83-93.

Sadori, L., Koutsodendris, A., Panagiotopoulos, K., Masi, A., Bertini, A., Combourieu-Nebout, N., Francke, A., Kouli, K., Joannin, S., Mercuri, A.M., Peyron, O., Torri, P., Wagner, B., Zanchetta, G., Sinopoli, G., and Donders, T.H., 2016. Pollen-based paleoenvironmental and paleoclimatic change at 
Lake Ohrid (south-eastern Europe) during the past $500 \mathrm{k}$. Biogeosciences, 13: 1423-1437.

Stockmar, J., 1971. Tablets with spores used in absolute pollen analysis. Polen et Spores, 13: 615-621.

Skrzypek, G., Jędrysek, M.O., Keller-Sikora, A., 2005. Calibration of temperature carbon isotopic effect (peat bogs Hala Izerska, Izerskie Mts. and Szrenica, Karkonosze Mts.). Polish Geological Institute Special Papers, 16: 123-126.

Skrzypek, G., Kałużny, A., Jędrysek, M-O., 2007a. Carbon stable isotope analyses of mosses- comparisons of bulk organic matter and extracted nitrocellulose. Journal of the American Society for Mass Spectrometry, 18: 1453-1458.

Skrzypek, G., Kałużny, A., Wojtuń, B., Jeedrysek, M-O., 2007b. The carbon stable isotopic composition of mosses - the record of temperature variations. Organic Geochemistry, 38: 1770-1781.

Smith, B.N., Herath, H.M., Chase, J.B., 1973. Effect of growth temperature on carbon isotopic ratios in barley, pea and rape. Plant Cell Physiology, 14: 177-182.

Szymanek, M., 2017. Palaeotemperature estimation in the Holsteinian Interglacial (MIS 11) based on oxygen isotopes of aquatic gastropods from eastern Poland. Acta Geologica Polonica, 67: 585-605.

Szymanek, M., Bińka, K., Nitychoruk, J., 2016. Stable ${ }^{18} \mathrm{O}$ and ${ }^{13} \mathrm{C}$ isotope records of Viviparus diluvianus (Kunth, 1865) shells from Holsteinian (MIS 11) lakes of eastern Poland as palaeoenvironmental and palaeoclimatic proxies. Boreas, 45: 109-121.

Terpiłowski, S., Zieliński, T., Kusiak, J., Pidek, I.A., Czubla, P., Hrynowiecka, A., Godlewska, A., Zieliński, P., Małek, M., 2014. How to resolve Pleistocene stratigraphic problems by different methods? A case study from eastern Poland. Geological Quarterly 58 (2): 235-250.

Tye, G.J., Sherriff, J., Candy, I., Coxon, P., Palmer, A., McClymont, E.L., Schreve, D.C., 2016. The $\delta^{18} \mathrm{O}$ stratigraphy of the Hoxnian lacustrine sequence at Marks Tey, Essex, UK: implications for the climatic structure of MIS 11 in Britain. Journal of Quaternary Science, 31: 75-92.

Tzedakis, P.C., Andrieu, V., deBeaulieu, J.L., Crowhurst, S., Follieri, M., Hooghiemstra, H., Magri, D., Reille, M., Sadori, L., Shackleton, N.J., Wijmstra, T.A., 1997. Comparison of terrestrial and marine records of changing climate of the last 500,000 years. Earth and Planetary Science Letters, 150: 171-176.

Tzedakis, P.C., Andrieu, V., deBeaulieu, J.L., Birks, H.J.B., Crowhurst, S., Follieri, M., Hooghiemstra, H., Magri, D., Reille, M., Sadori, L., Shackleton, N.J., Wijmstra, T.A., 2001. Establishing a terrestrial chronological framework as a basis for biostratigraphical comparisons. Quaternary Science Review, 20: 1583-1592.

Tzedakis, P.C., Roucoux, K.H., DeAbreu, L., Shackleton, N.J., 2004. The duration of forest stages in southern Europe and interglacial climate variability. Science, 306: 2231-2235.

Tzedakis, P.C., Hooghiemstra, H., Pälike, H., 2006. The last 1.35 million years at Tenaghi Philippon: revised chronostratigraphy and long-term vegetation trends. Quaternary Science Reviews, 25: $3416-3430$
Tzedakis, P.C., Wolff, E.W., Skinner, L.C., Brovkin, V., Hodell, D.A., McManus, J.F., Raynaud, D., 2012. Can we predict the duration of an interglacial? Climate of the Past, 8: 1473-1485.

Vakhrameeva, P., Koutsodendris, A., Wulf, S., Fletcher, W., Appelt, O., Knipping, M., Gertisser, R., Trieloff, M., Pross, J., 2018. The cryptotephra record of the Marine Isotope Stage 12 to 10 interval (460-335 ka) at Tenaghi Philippon, Greece: exploring chronological markers for the Middle Pleistocene of the Mediterranean region. Quaternary Science Reviews, 200: 313-333.

Veres, D., Bazin, L., Landais, A., Kele, H.T.M., Lemieux-Dudon, B., Parrenin, F., Martinerie, P., Blayo, E., Blunier, T., Capron, E., Chappellaz, J., Rasmussen, S.O., Severi, M., Svensson, A., Vinther, B., Wolff, E.W., 2013. The Antarctic ice core chronology (AICC2012): an optimized multi-parameter and multi-site dating approach for the last 120 thousand years. Climate of the Past, 9: 1733-1748.

Voelker, A.H.L., Rodrigues, T., Billups, K., Oppo, D., McManus, J., Stein, R., Hefter, J., Grimalt, J.O., 2010. Variations in mid-latitude North Atlantic surface water properties during the mid-Brunhes (MIS 9-14) and their implications for the thermohaline circulation. Climate of the Past, 6: 531-552.

Vogel, H., Meyer-Jacob, C., Melles, M., Brigham-Grette, J., Andreev, A.A., Wennrich, V., Tarasov, P.E., Rosén, P., 2013. Detailed insight into Arctic climatic variability during MIS 11c at Lake El'gygytgyn, NE Russia. Climate of the Past, 9: 1467-1479.

Whelan, T., Sackett, W.M., Benedict, C.R., 1973. Enzymatic Fractionation of Carbon Isotopes by Phosphoenolpyruvate Carboxylase from C4 Plants. Plant Cell Physiology, 51: 1051-1054.

Winter, H., Urbański, K., 2007. New Mazovian Interglacial site at Gajec - Łagowskie Lakeland (Western Poland) (in Polish with English summary). Przegląd Geologiczny, 55: 330-335.

Zagwijn, W.H., 1996. The Cromerian Complex Stage of the Netherlands and correlation with other areas in Europe. In: The Early Middle Pleistocene in Europe (ed. Ch. Turner): 145-172. Balkema, Rotterdam.

Żarski, M., 2007. Szczegółowa Mapa Geologiczna Polski 1:50 000 ark. Adamów (in Polish). Państwowy Instytut Geologiczny, Warszawa.

Żarski, M., 2008. Objaśnienia tekstowe do Szczegółowej Mapy Geologicznej w skali 1:50 000 ark. Adamów (639) (in Polish). Państwowy Instytut Geologiczny, Warszawa.

Żarski, M., 2009. Szczegółowa Mapa Geologiczna Polski w skali 1:50 000 ark. Adamów (639) (in Polish). Państwowy Instytut Geologiczny, Warszawa.

Żarski, M., Morawski, M., 2013. Szczegółowa Mapa Geologiczna Polski 1:50 000 ark. Kaplonosy (in Polish). Państwowy Instytut Geologiczny, Warszawa.

Żarski, M., Nita, M., Winter, H., 2005. Nowe stanowiska interglacjalne w dolinie Wilgi i Okrzejki na wysoczyźnie Żelechowskiej (Polska południowo-wschodnia) (in Polish with English summary). Przeglad Geologiczny, 53: 37-44 .

Żarski M., Małek M., Albrycht A., 2009. Plejstocen południowego Podlasia (in Polish). In: XVI Konferencja Stratygrafia Plejstocenu Polski. Strefa marginalna zlodowacenia warty i pojezierza plejstoceńskie na południowym Podlasiu (eds. M. Żarski and S. Lisicki): 13-19. Zimna Woda k. Łukowa 31.08-4.09. 